University of New Hampshire

University of New Hampshire Scholars' Repository

Fall 2016

\title{
Developing a Chronology for Thinning of the Laurentide Ice Sheet in New Hampshire During the Last Deglaciation
}

Taylor Hodgdon

University of New Hampshire, Durham

Follow this and additional works at: https://scholars.unh.edu/thesis

\section{Recommended Citation}

Hodgdon, Taylor, "Developing a Chronology for Thinning of the Laurentide Ice Sheet in New Hampshire During the Last Deglaciation" (2016). Master's Theses and Capstones. 873.

https://scholars.unh.edu/thesis/873

This Thesis is brought to you for free and open access by the Student Scholarship at University of New Hampshire Scholars' Repository. It has been accepted for inclusion in Master's Theses and Capstones by an authorized administrator of University of New Hampshire Scholars' Repository. For more information, please contact Scholarly.Communication@unh.edu. 


\section{DEVELOPING A CHRONOLOGY FOR THINNING OF THE LAURENTIDE ICE SHEET IN NEW HAMPSHIRE DURING THE LAST DEGLACIATION}

by

Taylor Hodgdon

B.S. Geology, University of New Hampshire, 2014

\section{THESIS}

Submitted to the University of New Hampshire in Partial Fulfillment of

the Requirements for the Degree of

Master of Science

in

Earth Science: Geology

September, 2016 
This thesis has been examined and approved in partial fulfillment of the requirements for the degree of Master of Science in Earth Sciences by:

Thesis Director, Joseph M. Licciardi, Associate Professor of Earth Sciences

Michael Palace, Associate Professor of Environmental Sciences, Geospatial Analysis and Remote Sensing

Thompson Davis, Professor of Natural and Applied Sciences at Bentley University

On June 27, 2016

Original approval signatures are on file with the University of New Hampshire Graduate School. 


\section{ACKNOWLEDGEMENTS}

I would first like to thank my thesis advisor, Joe Licciardi, who has guided me through the development and competition of this research project. Joe has played an instrumental role in this thesis research, from teaching me proper lab procedures to helping me develop overarching research questions. Joe has helped me become a more critical thinker and grow as a scientist through his unwavering support and encouragement. Without Joe's support and knowledge this thesis research would not have been possible. I would also like to thank my thesis committee members, Mike Palace and Thom Davis for all of their insight and help interpreting field data. I also appreciate all of the time Mike spent teaching me how to model ice sheets using ArcGIS.

Thank you also to my dedicated group of field assistants including: Scott Hodgdon, Grace Delgado, Sarah Widlansky, Sophie White, Jillian Swist, Avy Schweinsberg, Ian Henry, Stephany Gebo, and Julia Dalton. I am grateful to Mike Routhier who spent countless hours teaching me the different functions of ArcGIS and to Nate Hastings and William McKernan who helped me generate figures using Adobe Photoshop. I would also like to thank Susan Zimmerman and Alan Hidy at the Center for Accelerator Mass Spectrometry at Lawrence Livermore National Laboratory who provided assistance with the analysis and calculation of our exposure ages.

This research project would not have been possible without generous funding in the form of a graduate assistantship through the Memorial Union Building, a research grant from the University of New Hampshire Department of Earth Sciences, a graduate student research grant from the Geological Society of America, a research grant from the Sigma Xi Scientific Research Society, and a scholarship from Jon Herndon. 


\section{TABLE OF CONTENTS}

ACKNOWLEDGEMENTS............................................................ ii

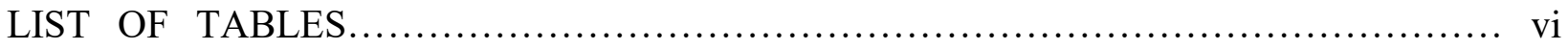

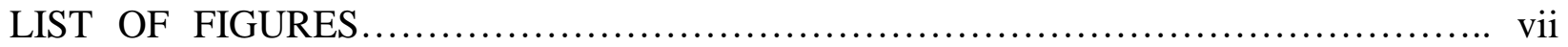

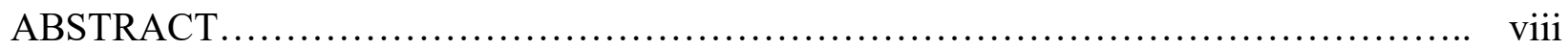

$\begin{array}{ll}\text { CHAPTER } & \text { PAGE }\end{array}$

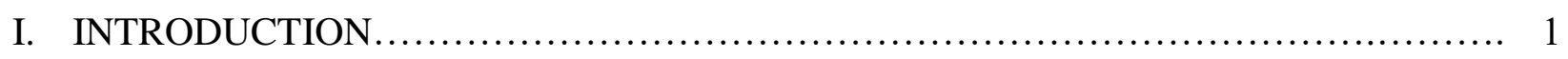

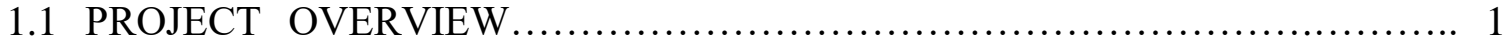

1.2 GEOLOGIC SETTING...................................................... 3

1.3 ICE RETREAT CHRONOLOGY ........................................... 4

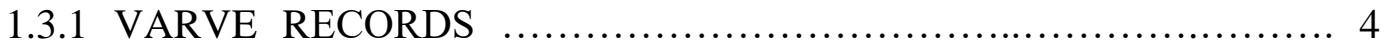

1.3.2 RADIOCARBON DATED LAKE SEDIMENT RECORDS............. 6

1.3.3 COSMOGENIC ${ }^{10} \mathrm{BE}$ EXPOSURE AGES............................ 8

1.4 ICE SHEET THINNING CHRONOLOGY .................................. 9

1.5 ICE FLOW PATTERNS................................................... 11

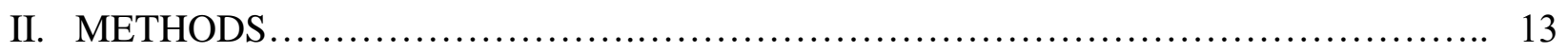

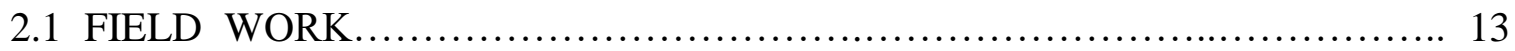

2.2 SAMPLE PREPARATION \& ANALYSIS ….............................. 15

2.3 MAPPING STRIATIONS IN ARCGIS …............................... 16

2.4 ICE SHEET PROFILES............................................... 17

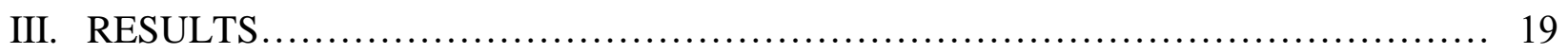

3.1 COSMOGENIC ${ }^{10} \mathrm{BE}$ EXPOSURE AGES ...................................19

3.2 ICE FLOW PATTERNS.................................................. 24 
IV. DISCUSSION AND INTERPRETATIONS ................................... 26

4.1 COMPARISON OF ${ }^{10} \mathrm{BE}$ AGES FROM SAMPLE SUMMITS .................. 26

4.2 COMPARISON TO PREVIOUSLY REPORTED CHRONOLOGY................ 28

4.3 ICE FLOW PATTERNS......................................................... 31

4.4 ICE SHEET PROFILES.................................................. 31

4.5 ICE SHEET SURFACE MODELS ............................................ 33

4.6 PALEOCLIMATIC INTERPRETATIONS................................... 35

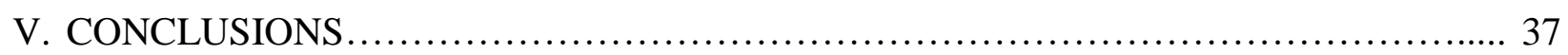

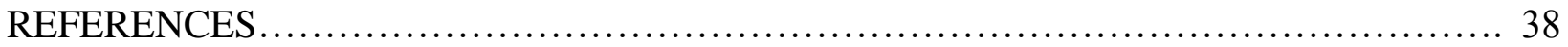

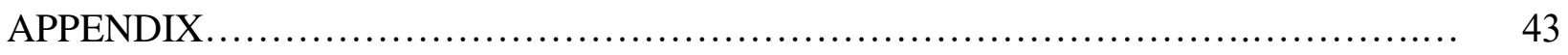




\section{LIST OF TABLES}

TABLE

PAGE

01. ${ }^{10} \mathrm{BE}$ EXPOSURE AGE RESULTS .............................................. 19

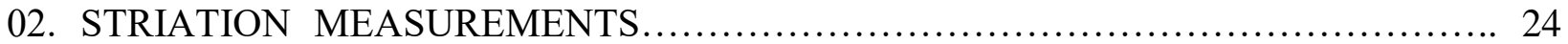

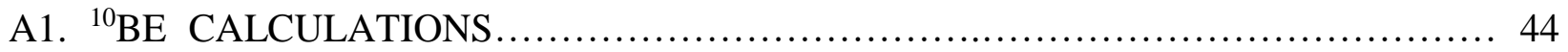

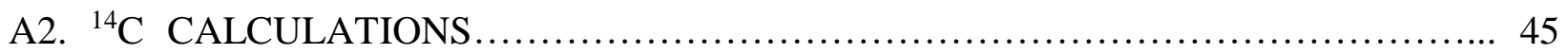

A3. DATA FOR ${ }^{10}$ BE CALCULATIONS ................................................. 46 


\section{LIST OF FIGURES}

FIGURE

PAGE

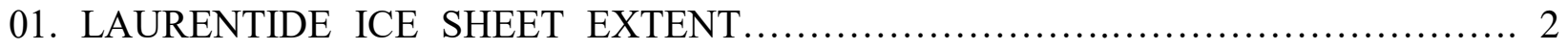

02. NORTH AMERICAN VARVE CHRONOLOGY ................................. 5

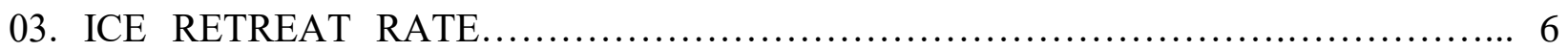

04. LAKE SEDIMENT CORE ${ }^{14} \mathrm{C}$ AGES.................................................. 7

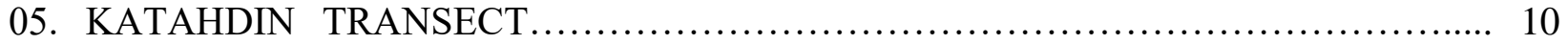

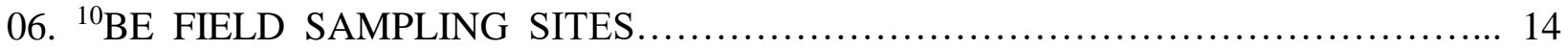

07. ICE SHEET THINNING SCHEMATIC......................................... 18

08a-d. ${ }^{10} \mathrm{BE}$ AND STRIATION RESULTS............................................ 20

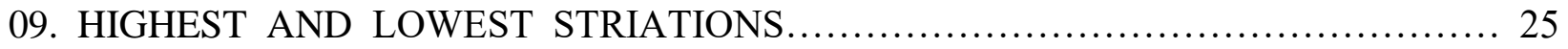

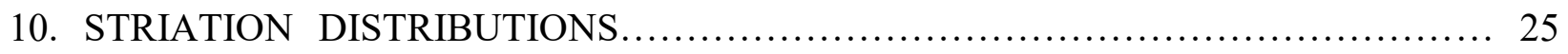

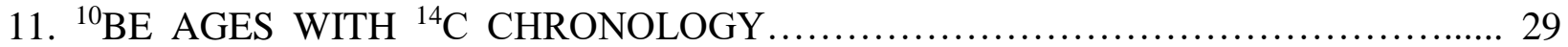

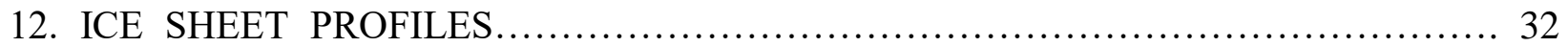

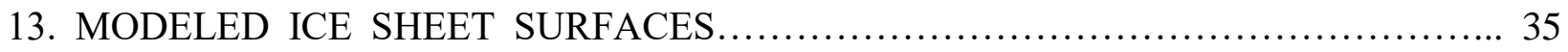




\begin{abstract}
DEVELOPING A CHRONOLOGY FOR THINNING OF THE LAURENTIDE ICE SHEET IN NEW HAMPSHIRE DURING THE LAST DEGLACIATION
\end{abstract}

by

Taylor Hodgdon

University of New Hampshire, September 2016

Well-constrained ages for the retreat of the Laurentide Ice Sheet (LIS) have been developed at key sites throughout New England, providing a framework for the deglacial history of the region. Previous work has focused primarily on documenting retreat of the ice sheet margin, but few studies have attempted to reconstruct changes in ice sheet geometry and flow patterns during its recession. This study provides the first direct age control on the thinning of the LIS in central and southern New Hampshire during the last deglaciation. In situ cosmogenic ${ }^{10} \mathrm{Be}$ exposure ages were developed from four glaciated summits, in order to determine when each mountain top emerged from the ice as it thinned. Exposure ages indicate the southernmost summit in the study (Mt. Monadnock) was exposed at $15.4 \pm 0.2 \mathrm{ka}$, and the northernmost peak (Mt. Dickey) was exposed at $13.1 \pm 0.2 \mathrm{ka}$. This age range supports a period of rapid ice surface lowering in New England. Striation measurements collected both from this study and previously published literature were analyzed to observe how ice flow patterns evolved in this region. The striations at the lowest elevations display a wider azimuthal range than those found at the highest 
elevations, indicating the development of strong topographic control on ice flow as thinning occurred. Three-dimensional ice sheet surfaces were modeled to display changes in ice sheet geometry, and suggest an increased rate of thinning from $1 \mathrm{~m} / \mathrm{yr}$ to $2 \mathrm{~m} / \mathrm{yr}$ at $\sim 15 \mathrm{ka}$ coinciding with the start of the Bølling Allerød warm period. This study provides valuable new insight on LIS thinning and flow patterns in New Hampshire and suggests potential links between changes in ice sheet geometry and regional paleoclimate forcings. 


\section{Chapter I: Introduction}

\section{1: Project Overview}

New England has long been the focus of glacial-geologic studies due to the abundance of glacial features covering the landscape. Agassiz (1870) was one of the first to provide evidence that glaciers once occupied the White Mountains. Early hypotheses stated that this region was dominated solely by alpine glaciers due to lack of "grooved patterns" outside of the White Mountains (Jackson, 1844). The hypothesis for a continental ice sheet in New Hampshire was not proposed until many years later and was not widely accepted until the work of Goldthwait (1916). The Laurentide Ice Sheet (LIS) reached its maximum extent (Fig. 1) in New England 26.1 ka (Balco et al., 2002; Balco et al, 2009) at the onset of the Last Glacial Maximum (LGM) between 26.5 and $20 \mathrm{ka}$ (Clark et al., 2009). The chronology of ice recession in New England since the LGM is based primarily on basal ${ }^{14} \mathrm{C}$ ages from modern lacustrine environments and varve records in proglacial lake sediments (Thompson et al., 1999; Ridge and Toll, 1999). These records indicate rapid retreat, roughly $300 \mathrm{~m} / \mathrm{yr}$, of the LIS margin across New Hampshire during the last deglaciation (Ridge et al., 2012). However, the radiocarbon and varve-based records rely on indirect dating of ice margin positions and do not provide any detail on ice sheet surface geometry. Recent studies have employed cosmogenic nuclide surface exposure dating on moraines and bedrock surfaces throughout New England (Balco et al, 2002; Balco et al., 2009, Bromley et al., 2015, Bierman et al., 2015; Davis et al., 2015) to refine the retreat chronology of the LIS. However, only two studies in this region have attempted to develop a timeline for ice surface lowering (Davis et al., 2015; Bierman et al., 2015). When ice thinning and margin retreat chronologies are combined they provide a view of LIS surface geometry and volume that can be 
used to determine how the ice sheet responded to climatic changes during recession. Thus, the primary objective of this study is to develop a chronology for thinning of the LIS using in situ ${ }^{10} \mathrm{Be}$ exposure dating of surfaces on once-glaciated summits in south-central New Hampshire. Another objective of this study is to combine cosmogenic ${ }^{10} \mathrm{Be}$ ages and striation measurements from this study with previously documented ice flow measurements and ${ }^{14} \mathrm{C}$ ages on ice margin positions so that ice sheet surfaces can be reconstructed to track changes in LIS geometry through time.

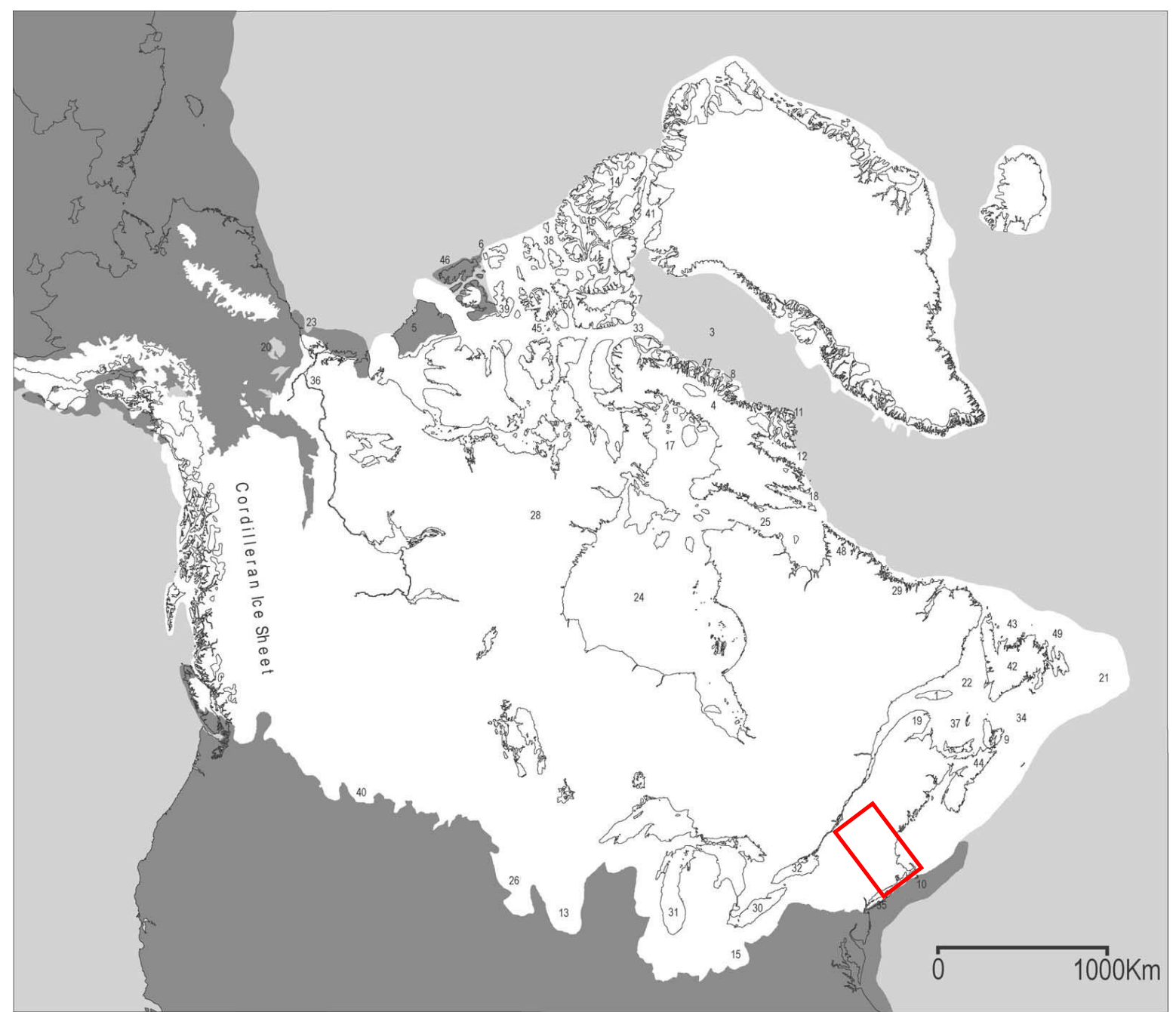

Figure 1: Map of Laurentide Ice Sheet during the height of the Last Glacial Maximum (Dyke et al., 2002). The red box marks the extent of the New Hampshire area. 


\section{2: Geologic Setting}

This study focuses on central and southern New Hampshire, which represents a large geographic gap in the documented chronology of LIS retreat. Bedrock in New Hampshire is composed primarily of metamorphic and metasedimentary units that formed during the orogenies responsible for the uplift of the Appalachian mountain range. These units form the backbone of the Appalachians in New Hampshire and are dominated by micaceous schists and phyllites (Lyons et al., 1997). The metamorphic basement rocks were later intruded by two plutonic units comprising the White Mountain Magma Series (220-155 Ma) and the New Hampshire Plutonic Series (130-100 Ma), which are composed primarily of felsic igneous rocks rich in quartz and silica bearing minerals (Creasy and Eby, 1993). The peaks sampled in this study include Mts. Monadnock, Cardigan, Dickey, Major, Kearsarge, and Chocorua. Mts. Monadnock and Cardigan are composed primarily of folded schists but have an abundance of large quartz veins across the summits that formed due to stresses on the bedrock. Mt. Dickey is composed of granitic units containing an abundance of quartz and feldspars. The summit of Mt. Major consists of two major lithologic units, one composed of granite rich in plagioclase megacrysts and the other a quartz syenite. Each peak, with the exception of Mt. Chocorua, also retains glacial striae and in some cases glacial polish on bedrock, indicating original ice-sculpted surfaces. The abundance of original surfaces and the presence of quartz on these peaks provide ideal targets for ${ }^{10} \mathrm{Be}$ exposure dating. 


\section{3: LIS Retreat Chronology}

\subsection{1: Varve Records}

Varve records are a critical proxy for dating LIS recession as varves form in proglacial lake environments where annual sediment layers are deposited from glacial meltwater. Sediment layers in varve sequences typically fine upwards, displaying the loss of energy for a specific site through time as it becomes more distal to the ice margin (Benn and Evans, 2010). Coarsegrained basal varve layers resting directly on till are interpreted as minimum age markers for an ice sheet's margin because they mark the time and location of sediment deposition immediately following ice recession. Cores of varved sediments collected along transects in the general direction of ice recession can therefore be used to develop a retreat chronology for an ice sheet using basal layers in each core. Early efforts to piece together a chronology associated with the LIS were led by Antevs (1922) who documented the first glacial varves in the Connecticut River valley associated with Glacial Lake Hitchcock. The varve record complied by Antevs (1922, 1928) provided the first estimate of retreat rate of $73 \mathrm{~m} / \mathrm{yr}$ for the LIS in New Hampshire and also supplied the first evidence of a readvance associated with the Littleton-Bethlehem recessional moraine. Alone, varve sequences only provide a "floating" chronology of ice recession, but they can be tied to calendar ages through correlation with ${ }^{14} \mathrm{C}$ dated layers (Ridge, 2003).

Two primary methods have been employed to establish the New England Varve Chronology sequence provided by Antevs (1922, 1928): paleomagnetism and radiocarbon dating. McNish and Johnson (1938) and Johnson et al. (1948) were the first to use the remnant declination of varve layers in the Upper Connecticut River Valley to correlate sequences of 
varves between core sites to identify overlapping chronologies. Later radiocarbon dating of both basal and ice-proximal varves was used by Ridge and Larson (1990) and Ridge and Toll (1999) to date fossils and organic matter found within Glacial Lakes Hitchcock and Merrimack, providing a framework for the calibration of the New England Varve record to calendar ages. Later, the New England Varve Chronology was recalibrated and renamed the North American Varve Chronology by Ridge (2012) after finding the New England Varve Chronology was missing varve layers. Ridge (2012) recalibrated $54{ }^{14} \mathrm{C}$ ages from the original New England Varve record using CALIB 6.0 and IntCal09 to fill previous gaps, most notably in Claremont N.H. (CL), generating an updated and unified varve record (Fig. 2). Calibrated basal ${ }^{14} \mathrm{C}$ ages of varves from Glacial Lake Hitchcock place the margin of the LIS at the southernmost border of

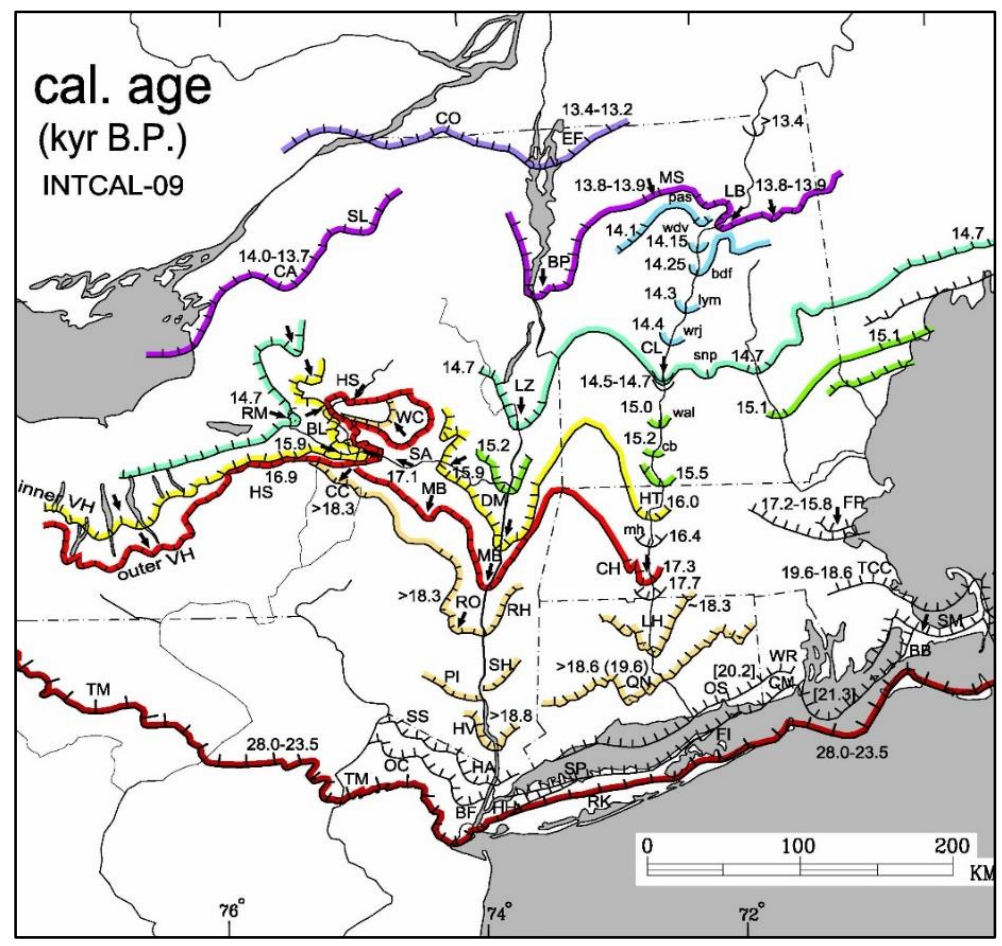

Figure 2: Map of basal ${ }^{14} \mathrm{C}$ ages from North American Varve Chronology record. Ages are calibrated using CALIB 6.0 and INTCAL09. Letters indicate specific moraine sequences or locations: LB $=$ Littleton-Bethlehem moraine, $\mathrm{CL}=$ Claremont N.H., BB = Buzzards Bay (Ridge 2003, updated http://eos.tufts.edu/varves/ navc).

New Hampshire at $15.5 \mathrm{cal} \mathrm{ka}$ and $13.4 \mathrm{cal}$ ka near the northern tip of the state (Ridge, 2003). Varve ages from south of Claremont document an ice retreat rate of roughly $90 \mathrm{~m} / \mathrm{yr}$ between 15.5 to $14.6 \mathrm{cal}$ ka (Ridge, 2003), slightly higher than the rate originally proposed by Antevs 
(1922, 1928). After $14.6 \mathrm{cal}$ ka the rate of retreat increases to $300 \mathrm{~m} / \mathrm{yr}$ until a pause or readvance occurs during the deposition of the Littleton-Bethlehem moraine sequence at $13.8 \mathrm{cal}$ ka (Figure 3; Ridge, 2012).

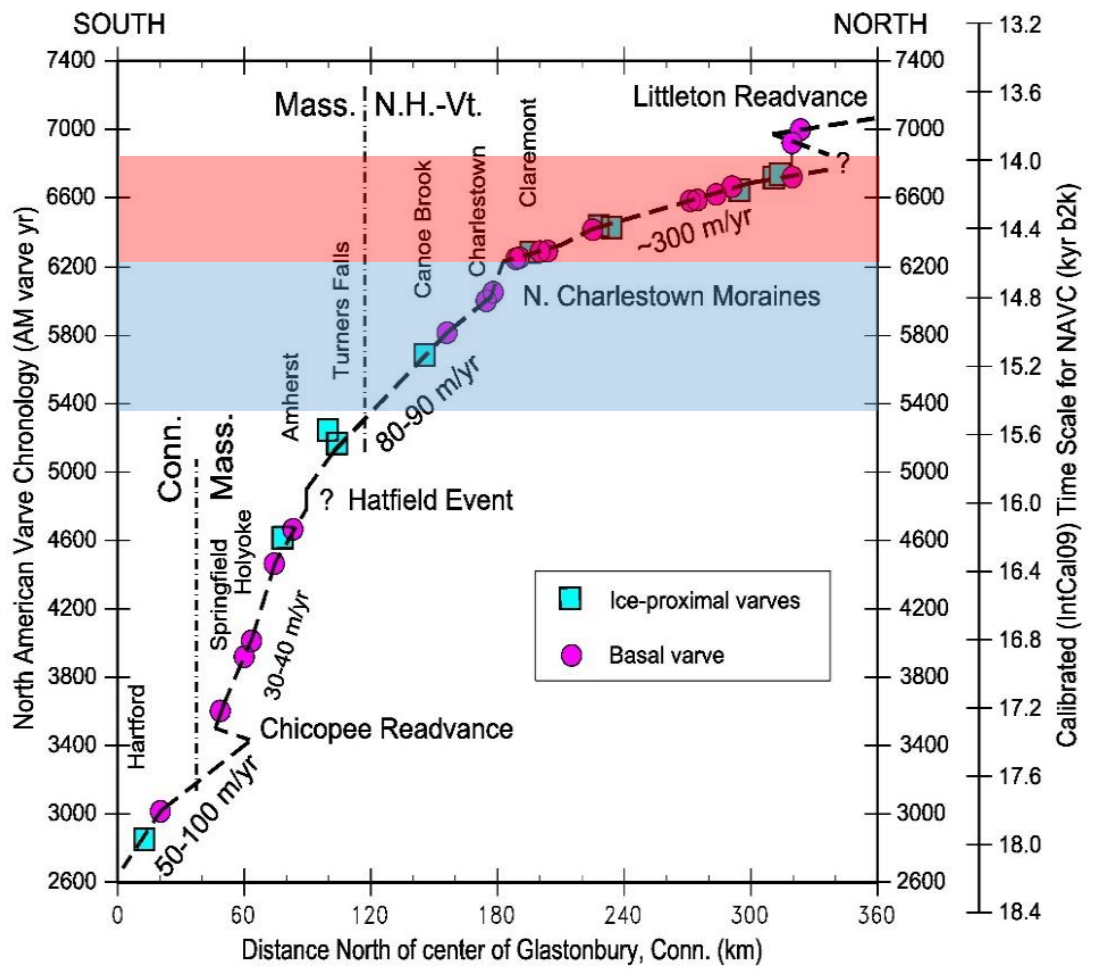

Figure 3: Transect of ${ }^{14} \mathrm{C}$ ages in basal and iceproximal varves from Glacial Lake Hitchcock. Transect starts at southern margin of Glacial Lake Hitchcock and ends at the northern margin. Corresponding varve years are seen in relation to ${ }^{14} \mathrm{C}$ ages. Blue section displays retreat rate of ice from 15.5 to $14.6 \mathrm{ka}$. Red section displays increased retreat rate from 14.6 to $13.8 \mathrm{ka}$. (Ridge et al., 2012).

\subsection{2: Radiocarbon Dated Lake Sediment Records}

Thompson et al. (1999) attempted to refine the chronology of deglaciation in northern New Hampshire through radiocarbon dating of sediment cores recovered from modern lacustrine environments. Similar to varves, when lake sediments are found directly overlying glacial till, the basal layers of the core are interpreted to provide minimum ages of ice retreat. These ages are likely to be younger than the actual timing of deglaciation due to a lag time effect that occurs when terrestrial organisms die and have a prolonged transport time until they are finally deposited in lake sediments (Davis and Davis, 1980). Another potential issue is ecesis, the time 
required for plants to become established in recently deglaciated landscapes (Sigafoos and Hendricks, 1969). Therefore, the basal ${ }^{14} \mathrm{C}$ ages developed in lake cores provide only minimum limiting ages associated with deglaciation.

Thompson et al. (1999) compiled basal ${ }^{14} \mathrm{C}$ ages from 15 lake sediment cores north of the White Mountains (Fig.4) and found a close correlation to the timing of deglaciation associated with the North American Varve Chronology record, further strengthening the ice retreat chronology. The Littleton-Bethlehem moraine complex was a main focus of this study as it was thought to mark a period of readvance for the LIS. Recalibrated basal ${ }^{14} \mathrm{C}$ ages collected just south of the moraine complex (Table A2) suggest deposition occurred roughly 14.6 cal ka directly preceding the Older Dryas, a brief 200 year-long cold interval that occurred roughly 13.9 $\mathrm{ka}$, in the middle of the Bølling Allerød warming period (Iverson, 1953). While radiocarbon dating has proven useful for developing an initial chronology of ice recession in New England, its use is limited to areas containing dateable organic materials, such as once-active glacial lakes and modern lacustrine/bog environments.

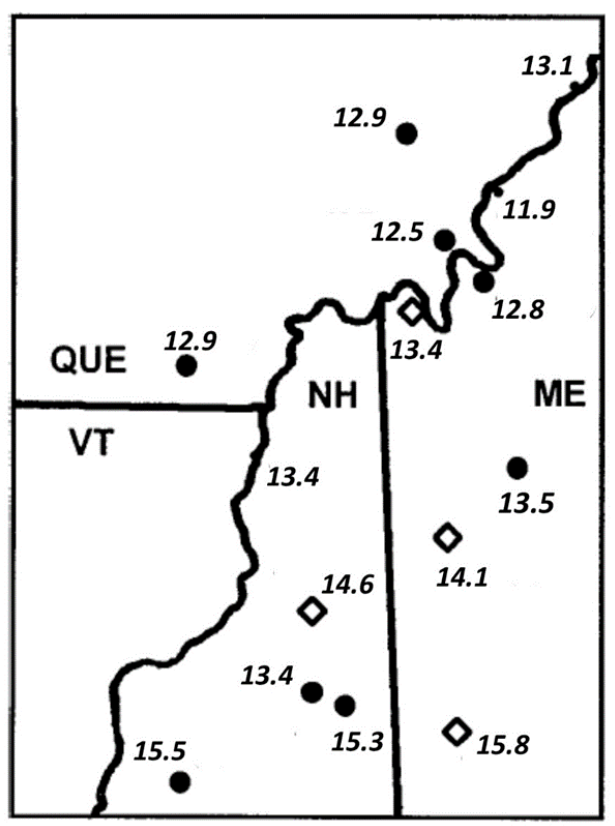

Figure 4: Recalibrated basal ${ }^{14} \mathrm{C}$ ages from lake sediment cores in northern New England (Thompson et al., 1999). Littleton-Bethlehem moraine sequence is located between (4) and (5). 


\subsection{3: Cosmogenic ${ }^{10} \mathrm{Be}$ Exposure Ages}

To further constrain the LIS retreat chronology, cosmogenic ${ }^{10} \mathrm{Be}$ exposure dating has been utilized on bedrock and glacial erratics in parts of New England. One major advantage of

${ }^{10} \mathrm{Be}$ exposure dating is that it allows for the direct dating of glacial features and comparison of the dated landforms to known climatic events. All ${ }^{10} \mathrm{Be}$ ages reported and discussed in this study are calculated using the regional production rate from Balco et al. (2009) (See Table A1). One of the earliest ${ }^{10} \mathrm{Be}$ exposure dating studies in New England was conducted on the Martha's Vineyard terminal moraine and Buzzards Bay recessional moraine in Massachusetts (Balco et al., 2002). The results from this study indicate that the maximum extent of the LIS occurred in New England about $26.1 \pm 1.5 \mathrm{ka}$ (Balco et al., 2002), which is consistent with radiocarbon ages that bracket the moraine between 28.0-23.6 cal ka (Davis and Jacobson, 1985). Located roughly 2 $\mathrm{km}$ north of the Martha's Vineyard moraine, the Buzzards Bay recessional moraine has ages of $20.8 \pm 1.3 \mathrm{ka}$, indicating marginal retreat during the initial phase of deglaciation (Balco et al., 2002).

Focusing in New Hampshire, ${ }^{10}$ Be exposure ages were developed from the Androscoggin and Littleton-Bethlehem moraine complexes located in northern New Hampshire (Bromley et al., 2015). These two prominent moraine complexes are located at roughly the same latitude and are separated by about $30 \mathrm{~km}$ (Bromley et al., 2015). ${ }^{10} \mathrm{Be}$ ages obtained from the crest of the Androscoggin moraine date yield a mean age of $13.2 \pm 0.4 \mathrm{ka}$, which corresponds within $1 \sigma$ uncertainty to a mean age of $13.8 \pm 0.2 \mathrm{ka}$ from the eastern portion of the Littleton-Bethlehem moraine (Bromley et al., 2015). This pause in deglaciation has been attributed to a colder period 
of the Allerød, as suggested earlier by Thompson et al. (1999) to explain the deposition of the Littleton-Bethlehem moraine.

\section{4: LIS Thinning Chronology}

While recession of the ice margin throughout New Hampshire is relatively well documented, the pattern of thinning for the LIS is not well understood. Several studies have used numerical modeling to simulate how the LIS thinned while it receded through North America (Licciardi et al., 1998; Marshall et al., 2000; Peltier, 2004). While the models predict varying maximum ice thicknesses in central portions of the LIS, all of these simulations estimate an ice sheet thickness of $\sim 2 \mathrm{~km}$ in New Hampshire during the LGM. Modeling studies have also provided insight on how the surface geometry of the LIS evolved through the deglaciation and how it may have responded to climatic events.

In addition to modeling, two recent studies have attempted to reconstruct changes in ice sheet surface geometry through ${ }^{10} \mathrm{Be}$ exposure dating of once-glaciated summits. By matching ${ }^{10} \mathrm{Be}$ ages from the summits of mountains with ice marginal features of similar age to the south, ice sheet profiles can be generated. Davis et al. (2015) followed this approach in Maine and produced an ice sheet profile connecting the Basin Ponds moraine at the base of Mt. Katahdin to the Pineo Ridge moraine system near the Maine seacoast (Fig. 5). Cosmogenic ${ }^{10}$ Be exposure ages were obtained from samples located on both the summit areas and from moraines deposited on the eastern flank of the mountain. An average age of $15.3 \pm 2.1$ ka was calculated from six samples on the Katahdin uplands, and interpreted to reflect when the summit initially emerged through the ice sheet as a nunatak (Davis et al., 2015). Six ages from Basin Ponds moraine provide an average age of $16.1 \pm 1.2 \mathrm{ka}$, indicating rapid thinning of LIS ice that occurred in this 
area (Davis et al., 2015). The Pineo Ridge moraine system, $200 \mathrm{~km}$ southeast from Mt Katahdin has an average exposure age of $17.5 \pm 1.1 \mathrm{ka}$. Ages from this moraine are consistent within $1 \sigma$ uncertainty of the ages developed from the Basin Ponds moraine at Katahdin, indicating that both of these moraines were likely deposited at the same time (Davis et al., 2015).

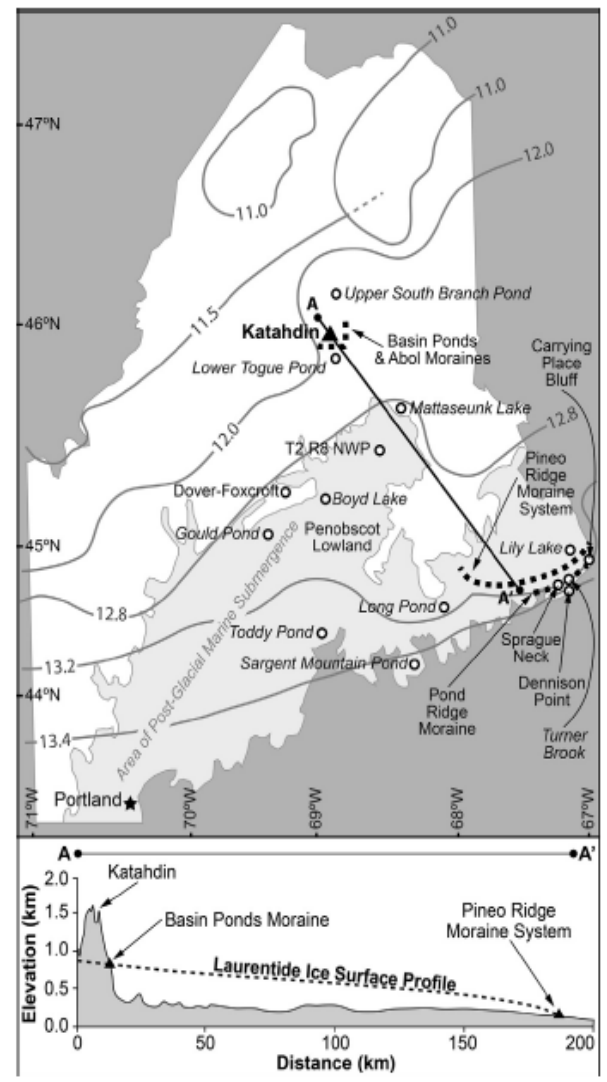

Figure 5: Transect and accompanying ice sheet profile connecting the Basin Ponds Moraine (Katahdin) and the Pineo Ridge Moraine System on the coast. Isochrones are shown in ${ }^{14} \mathrm{C}$ years and dashed black lines represent major moraine sequences (Davis et al., 2015).

In New Hampshire, the high summits of Mt. Washington and Little Haystack were sampled using ${ }^{10} \mathrm{Be}$ exposure dating to determine the time of deglaciation (Bierman et al., 2015). Five samples collected from the summit of Mt. Washington yielded ages ranging from $156 \mathrm{ka}$ to $17.9 \mathrm{ka}$ (Bierman et al., 2015). One sample from Little Haystack produced an age of $59.6 \mathrm{ka}$ (Bierman et al., 2015). These ages are not consistent with lowland ages, such as those developed in Maine (Davis et al., 2015). However, these older ages do provide valuable insight into the basal properties of the LIS at higher elevations. Bierman et al. (2015) concluded that the ice 
covering these high peaks was likely thin and weakly erosive, which may explain the presence of inherited nuclides that increase the exposure ages.

\section{5: LIS Flow Patterns}

Striations and other ice flow indicators provide a unique insight into the flow patterns of the ice sheets that created them. Numerous studies have examined ice flow patterns throughout New England to determine both regional and localized ice flow patterns for the LIS during and after the LGM (Hitchcock, 1878; Wheelock, 1873; Goldthwait et al., 1951; Wright, 2015). Regional ice flow in New England was generally south-southeast (Antevs, 1922), however localized flow patterns appear to vary drastically across the region (Wright, 2015). Several sites display zones of cross-cutting striations which indicate two different ice flow patterns at the same location. Early work by Wheelock (1873) first noted patterns of cross cutting striations on the south eastern face of Mount Monadnock. Subsequent work in the region provided detailed mapping of striations to depict higher resolution ice flow patterns (Billings, 1949). Zones of cross-cutting striations have also been noted throughout Vermont (Doll et al., 1970; Wright, 2015), all in areas of high topographic relief. Two hypotheses were developed by Wright (2015) to explain these localized ice flow changes. The first states that ice flow patterns may have shifted due to readvances in low-lying valleys. The second proposes that as the LIS thinned in the region, ice became topographically confined in low-lying valleys that once displayed regional ice flow patterns.

Recent ice flow studies have focused primarily on Vermont as there are over 2,000 striations that have been mapped in the state, providing a detailed view of ice flow. Some of the first striation data for Vermont were compiled by Flint (1957), who recognized distinct changes 
in ice flow at different elevations. Later, surficial mapping conducted by Stewart and MacClintock (1970) showed three distinct "till sheets" that formed across Vermont, and subsequent work by Larson (1972) and Munroe et al. (2007) utilized erratics and traced their lithologies back to the host rocks to determine ice flow direction. More recent ice flow work in Vermont by Wright (2015) has focused on the Champlain River valley and valleys east of the Green Mountains as thevalleys were a major output source for ice streaming from the LIS toward the end of the LGM. The results from Wright (2015) indicated that as the LIS thinned in Vermont, the ice no longer displayed the regional southeast ice flow pattern as it became topographically confined in two main north-south drainage valleys. Striations measured on the majority of summits and ridges in Vermont display a notable shift in dominant ice flow from southeast to south, parallel to the drainage basins. No similar studies on ice flow have been conducted in New Hampshire at this level of detail. 


\section{Chapter II: Methods}

\section{1: Field Work}

Samples were collected for ${ }^{10} \mathrm{Be}$ exposure dating during the summer of 2015 with access permits acquired from both the U.S Forest Service and the New Hampshire State Parks department. To attain a representative view of the retreat chronology and ice flow direction in New Hampshire, six mountains in the proposed field area were selected as the primary focus for the study: Mts. Monadnock, Cardigan, Major, Chocorua, Kearsarge, and Dickey (Fig. 6). These mountains were selected due to their exposed bedrock, preservation of striated landforms, rock type, and regional location. The peaks also serve to fill a geographic gap between the LIS extent and the Littleton-Bethlehem and Androscoggin moraine sequences where numerous retreat ages have been determined (Thompson et al., 1999, Balco et al., 2009, Bromley et al., 2015).

Samples from Mt. Major were all collected from the summit where bedrock surfaces are most abundant. Three of the four samples were taken from bedrock, two from the Albany Quartz Syenite and one from the Meredith Porphyritic Granite. The fourth sample was taken from a large erratic composed of an unknown granitic unit. Three samples from Mt. Cardigan were collected from quartz veins cutting across the bedrock near the summit and a fourth was collected from a quartz vein $60 \mathrm{~m}$ below the summit. Only three samples were collected from Mt. Dickey, two from bedrock surfaces on the summit and a third from bedrock $100 \mathrm{~m}$ below the summit along an exposed ridgeline. The four samples collected from Mt. Monadnock were all sampled from quartz veins with abundant striae on summit. Samples collected from Mts. Chocorua and Kearsarge were not processed due to low quality surfaces. 
Prior to sample removal, site details were recorded including: lithology and preservation of glacial features on or near the sample surface. Photographs were taken before and after each sample was collected to document the original surface and show the general setting in which each sample was taken. Latitude, longitude, and elevation were obtained using a handheld Garmin GPS. The strike, dip, and topographic shielding were recorded for each sampled surface in order to make corrections for the production of ${ }^{10} \mathrm{Be}$ at each site. On each mountain, striation orientations and locations were measured using a Brunton compass and GPS in order to document ice flow patterns.

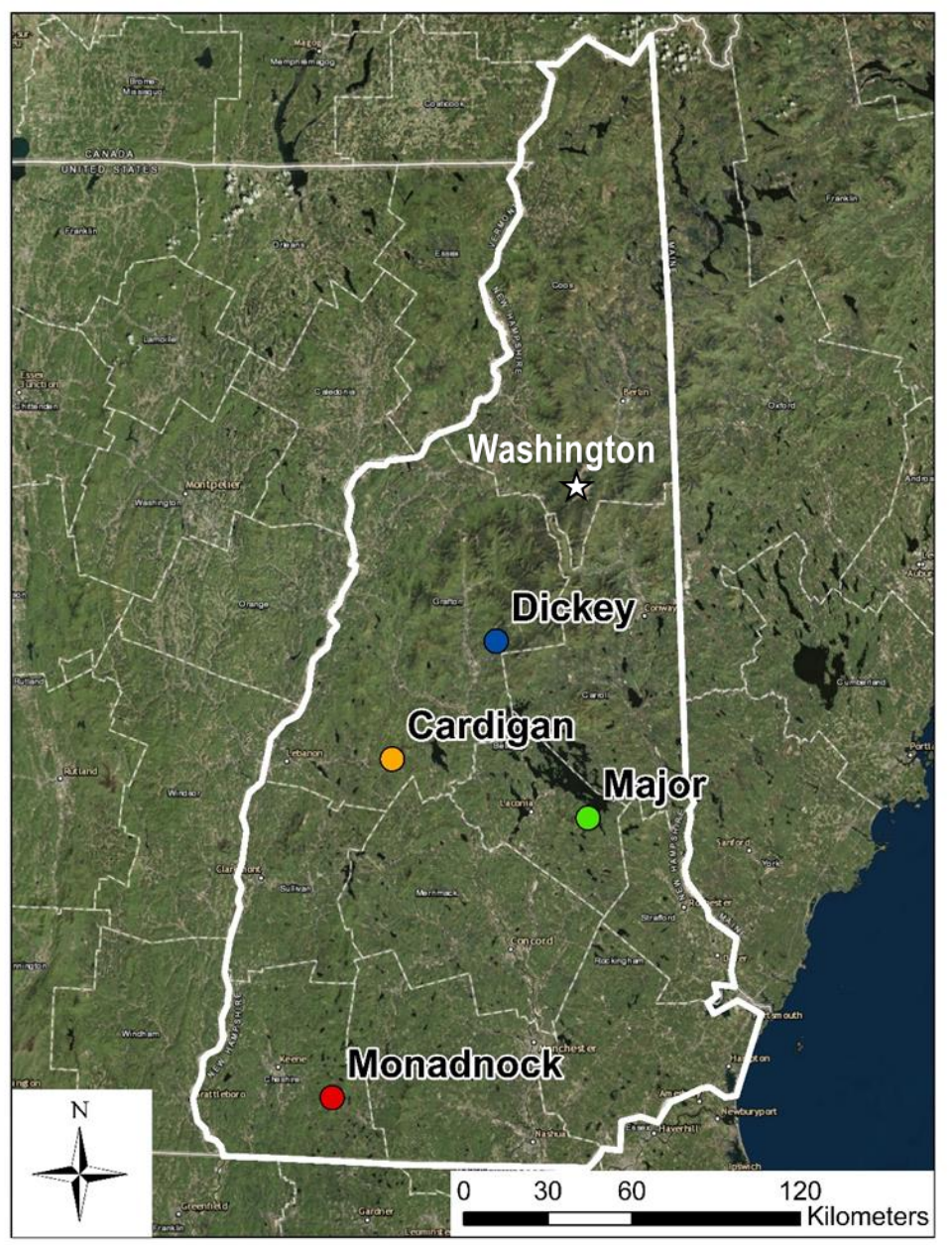

Figure 6: Map of sample sites in central and southern New Hampshire. Mts. Chocorua and Kearsarge not shown. 


\section{2: Sample Preparation and Analysis}

Samples were physically prepared in the rock preparation lab at the University of New

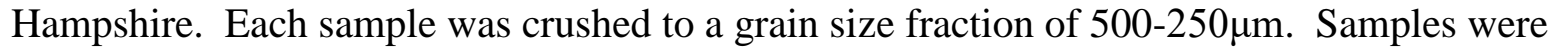
magnetically separated to remove the majority of mafic minerals from the sample. Froth flotation was used to remove the majority of non-quartz minerals using a mixture of carbonated dilute glacial acetic acid, laurylamine, and tea tree oil. To further purify the quartz, each sample was loaded into acid baths, first in a solution of hydrochloric acid to remove any carbonates, iron oxides, or organic materials, then in a solution of hydrofluoric and nitric acid to remove any nonquartz minerals and meteoric ${ }^{10} \mathrm{Be}$ (Kohl and Nishiizumi, 1992). After acid etching, quartz was tested for purity using an ICP-AES at the LEGS facility at the University of Colorado-Boulder.

Following a modified procedure from Licciardi (2000), each purified quartz sample was spiked with ${ }^{9} \mathrm{Be}$ carrier and then digested in concentrated hydrofluoric acid. Samples were then dried down, using perchloric acid hydrochloric acid to prepare samples for column procedures. Beryllium in each sample was isolated using ion exchange chromatography. Samples were precipitated into gels and then rinsed with DI water to remove any potential boron. Finally, the gels were oxidized to beryllium oxide powder and packed into cathodes to be analyzed using an accelerator mass spectrometer. Sample analysis was conducted at the Center for Accelerator Mass Spectrometry at the Lawrence Livermore National Laboratory in Livermore, California to determine the ${ }^{10} \mathrm{Be} /{ }^{9} \mathrm{Be}$ ratio of each sample required to calculate the exposure age. A process blank was prepared with the sample batch to assess laboratory and spike background.

Exposure ages were calculated using the CRONUS Earth online calculator (Balco et al., 2008) version 2.2.1 with the Northeast North America calibration data set (Balco et al., 2009). 
For samples composed of granitic bedrock, an average density of $2.7 \mathrm{~g} / \mathrm{cm}^{3}$ was used. Samples collected from quartz veins have an average density of $2.65 \mathrm{~g} / \mathrm{cm}^{3}$ (Table A3).

\section{3: Mapping Striations in ArcGIS}

ArcGIS 10.1 was used to analyze changing patterns of ice flow direction in relation to topography. In order to conduct this analysis, a 300m DEM of New Hampshire and the point glacial features data layers, containing 947 striation measurements, were obtained from New Hampshire GRANIT's online GIS data repository. All of the data layers were initially projected in ArcGIS using the same N.H. State Plane Projection to make sure the data were formatted and displayed in a consistent way. In order to fill a large geographic gap in the digitized striation data collected from New Hampshire, a surficial map published by Charles Hitchcock in 1878 containing 683 striation measurements was georectified using ArcMap. Corrections were made to the striation directions to account for changes in magnetic declination. The elevation of each striation was determined by joining the data to the 300m DEM data layer. A "fishnet" of 100 equal area cells was digitized over New Hampshire. The 100 highest and lowest elevation striations from each fishnet grid cell were then plotted. The difference between the highest and lowest elevation striations are used to interpret ice flow pattern changes in New Hampshire as ice sheet thinning occurred. The distributions of both striation data sets were then plotted on a rose diagram to display patterns of ice flow direction. ArcGIS was also used to map the ${ }^{10} \mathrm{Be}$ ages obtained from each field site. To show the relationship between the ${ }^{10} \mathrm{Be}$ exposure ages from this study and previously measured ${ }^{14} \mathrm{C}$ ages from varves and lake bottoms, ice recession chronology data from Ridge $(2003,2004)$ were digitized into ArcMap. 


\section{4: Ice Sheet Profiles}

Ice sheet surface profiles were generated from each sampled mountain to depict two dimensional reconstructions of the LIS surface geometry. To construct the ice sheet profiles, mean ${ }^{10} \mathrm{Be}$ ages from each site were correlated to independently dated ice marginal features such as varves and moraines. Features with the same age as the sampled summits would have been exposed at the same time, allowing for an ice sheet surface profile to be drawn between the two points (Fig. 7). Ice sheet profiles are typically constructed along a flow line, marking a specific portion of the ice sheet's flow pattern. The azimuthal directions of the flow lines used to generate the ice sheet profiles were determined using both striations measured in the field and previously mapped ice flow indicators.

A modeled ice sheet profile was generated for each site using Equation 1:

$$
H=\sqrt{\frac{2 \tau L}{\rho g}}
$$

where $\rho$ is the density of glacial ice $\left(900 \mathrm{~kg} / \mathrm{m}^{3}\right), \mathrm{H}$ is the thickness of the ice sheet, $\mathrm{L}$ is the distance from the sampled peak to the ice sheet margin, $g$ is gravity $\left(9.8 \mathrm{~m} / \mathrm{s}^{2}\right)$, and $\tau$ is the basal shear stress acting upon the glacier (Nye, 1952). An average basal shear stress of $100 \mathrm{kPa}$ was used for each peak (Cuffey and Peterson, 2010). This simplified equation is commonly used in glaciological studies to reconstruct past ice sheet profiles and is the basis of the ice profiler developed by Benn and Hulton (2010). When tested against observed modern ice sheet profiles in Greenland and Antarctica, the Nye (1952) equation produces very similar ice sheet profiles to what is seen today (Cuffey and Paterson, 2010). In Greenland, for example, the maximum 
thickness of the ice sheet is roughly $3.2 \mathrm{~km}$, based on geophysical measurements, and when using the profiler the maximum modeled thickness is $3.15 \mathrm{~km}$ (Cuffey and Paterson, 2010). This equation does not take into account changes in basal topography due to isostatic adjustment, and assumes a constant basal shear stress, but still provides accurate reconstructions. The equation used to generate the modeled ice sheet profiles was plotted against empirical ice sheet profiles to test if the ${ }^{10} \mathrm{Be}$ ages fit well within the previously established ice recession chronology. After the modelled ice sheet profiles were constructed, they were used to generate three-dimensional ice sheet surfaces in ArcGIS by pairing ice flow measurements with dated ice marginal features.
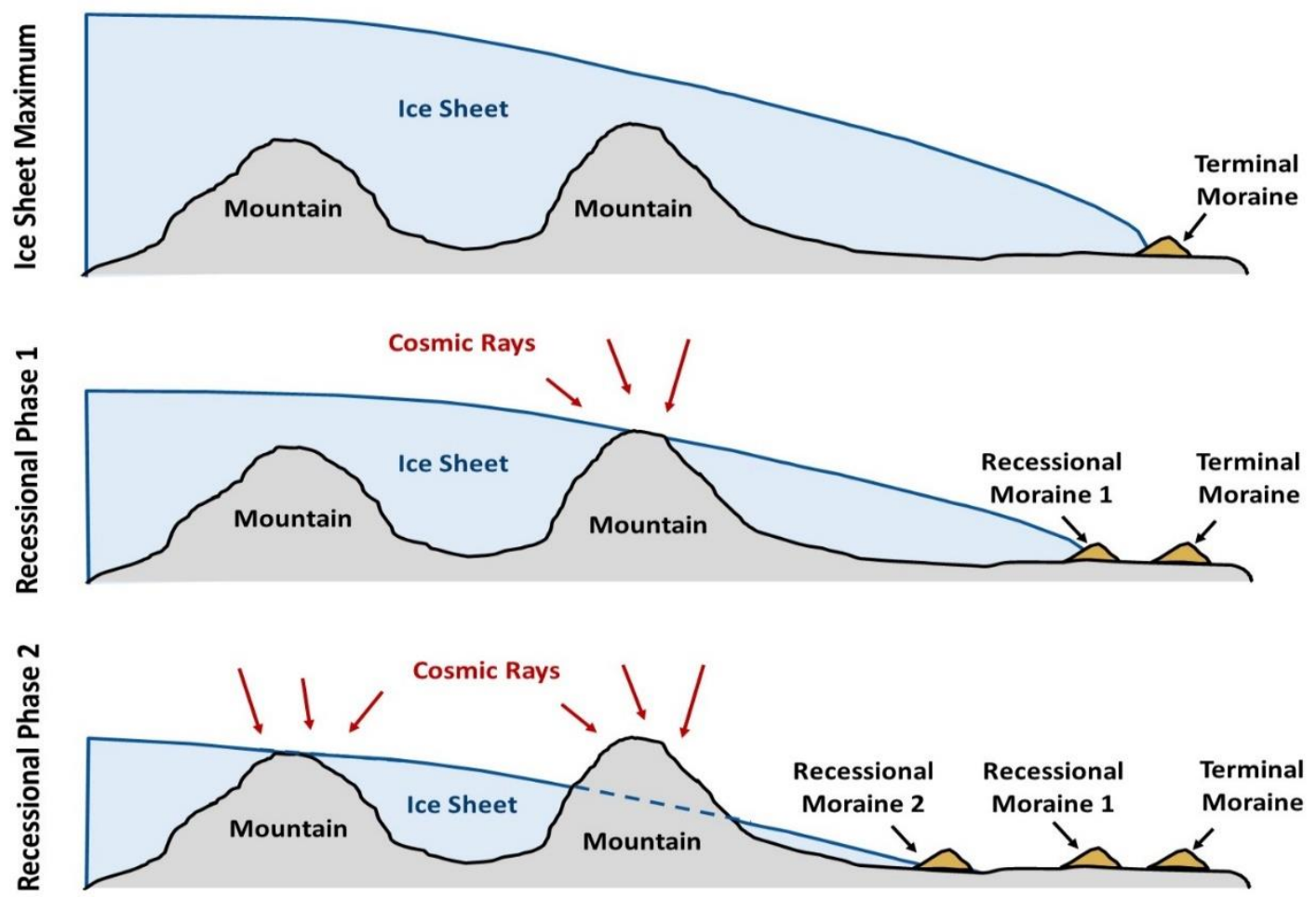

Figure 7: Schematic diagram depicting how an ice sheet thins as it recedes; mountain summits are the first topographic features to emerge from the ice sheet and interact with cosmic rays. 


\section{Chapter III: Results}

\section{$\underline{3.1{ }^{10} \mathrm{Be} \text { Surface Exposure Ages }}$}

The ${ }^{10} \mathrm{Be}$ concentrations and corresponding ages collected from each site are presented in Table 1. All ages were calculated using the Stone and Lal (St) scaling scheme (Lal, 1991; Stone, 2000; Balco et al., 2008). For comparison purposes, ages were also calculated using the LiftonSato-Dunai (LSDn) nuclide specific time-dependent scaling scheme (Lifton et al., 2014) and a production rate of 3.92 atoms/gram/year (Borchers et al., 2016); these ages are listed in Table 1 but all ages discussed in the text follow the NENA-St production rate and scaling scheme. Three samples from Mt. Monadnock (Fig. 8a) yielded an average exposure age of $15.4 \pm 0.2 \mathrm{ka}$, with no outliers. Mt. Major has a single age of 15.3 with an internal error of $0.5 \mathrm{ka}$ (Fig 8b). Mt. Cardigan has two exposure ages averaging $14.4 \pm 0.2$ (Fig 8c). Mt. Dickey has three exposure ages, two from the summit and one from roughly $100 \mathrm{~m}$ below the summit (Fig. 8d). Two samples collected from the summit of Mt. Dickey yield an average age of $12.9 \pm 0.1 \mathrm{ka}$, which is younger within internal uncertainty than the sample collected $100 \mathrm{~m}$ below the summit with an age of $13.6 \pm 0.2 \mathrm{ka}$.

\begin{tabular}{|c|c|c|c|c|c|c|c|}
\hline $\begin{array}{c}\text { Sample } \\
\text { Name }\end{array}$ & Location & $\begin{array}{c}{ }^{10} \text { Be Age } \\
\text { (LSDn) } \\
\text { (ka) }\end{array}$ & $\begin{array}{c}\text { External } \\
\text { Error } \\
\text { (ka) }\end{array}$ & $\begin{array}{c}{ }^{10} \mathrm{Be} \text { Age } \\
(\mathrm{NENA+St}) \\
(\mathbf{k a})\end{array}$ & $\begin{array}{c}\text { External } \\
\text { Error } \\
(\mathbf{k a})\end{array}$ & $\begin{array}{c}\text { Internal } \\
\text { Error } \\
\text { (ka) }\end{array}$ & $\begin{array}{c}\text { Average } \\
\text { NENA+St Age } \\
\text { (ka) }\end{array}$ \\
\hline NH15-04 & Mt. Major & 16.5 & 1.3 & 15.3 & 0.9 & 0.5 & - \\
\hline NH15-06 & Mt. Cardigan & 15.1 & 1.1 & 14.4 & 0.8 & 0.3 & \multirow{2}{*}{$14.4 \pm 0.2[0.5]$} \\
\hline NH15-08 & Mt. Cardigan & 15.2 & 1.1 & 14.4 & 0.8 & 0.3 & \\
\hline NH15-09 & Mt. Dickey & 13.6 & 1.1 & 12.8 & 0.7 & 0.3 & \multirow{3}{*}{$13.1 \pm 0.2[0.4]$} \\
\hline NH15-10 & Mt. Dickey & 13.7 & 1.1 & 12.9 & 0.7 & 0.3 & \\
\hline NH15-11 & Mt. Dickey & 14.5 & 1.1 & 13.6 & 0.7 & 0.3 & \\
\hline NH15-16 & Mt. Monadnock & 15.9 & 1.3 & 15.0 & 0.8 & 0.3 & \multirow{3}{*}{$15.4 \pm 0.2[0.5]$} \\
\hline NH15-17 & Mt. Monadnock & 16.1 & 1.2 & 15.2 & 0.8 & 0.3 & \\
\hline NH15-19 & Mt. Monadnock & 16.7 & 1.3 & 15.8 & 0.8 & 0.3 & \\
\hline
\end{tabular}

Table 1: ${ }^{10} \mathrm{Be}$ exposure age and associated internal and external error for each sample calculated using both the Lifton-Sato-Dunai (LSDn) nuclide + time dependent scaling scheme, and the New England North America (NENA) production rate with the Stone/Lal (St) time dependent scaling scheme. 


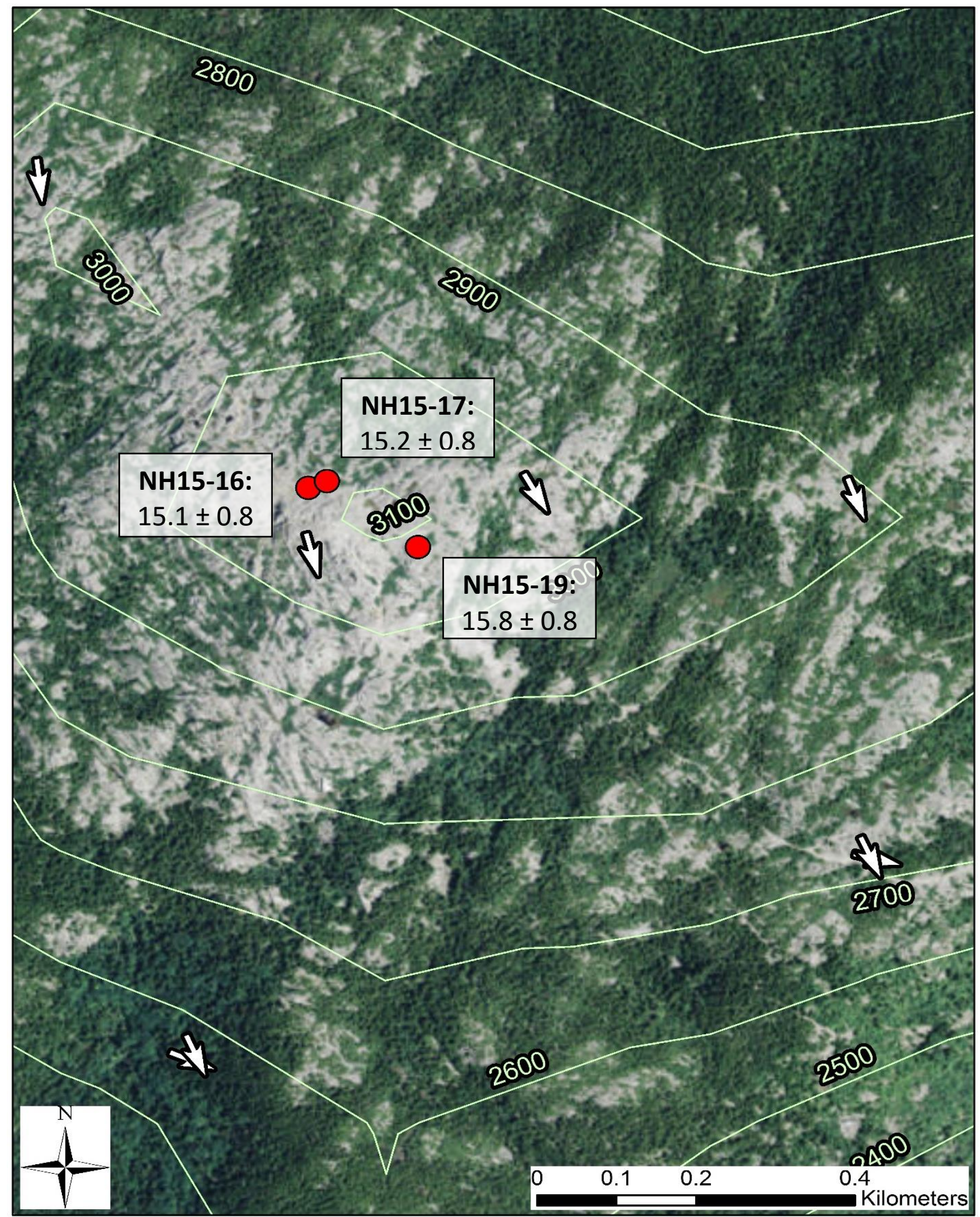

Figure 8a) Field map showing individual exposure ages and associated external errors on Mt.

Monadnock. Striations measurements are shown as white arrows (Billings, 1949). (Source data NH GRANIT) 


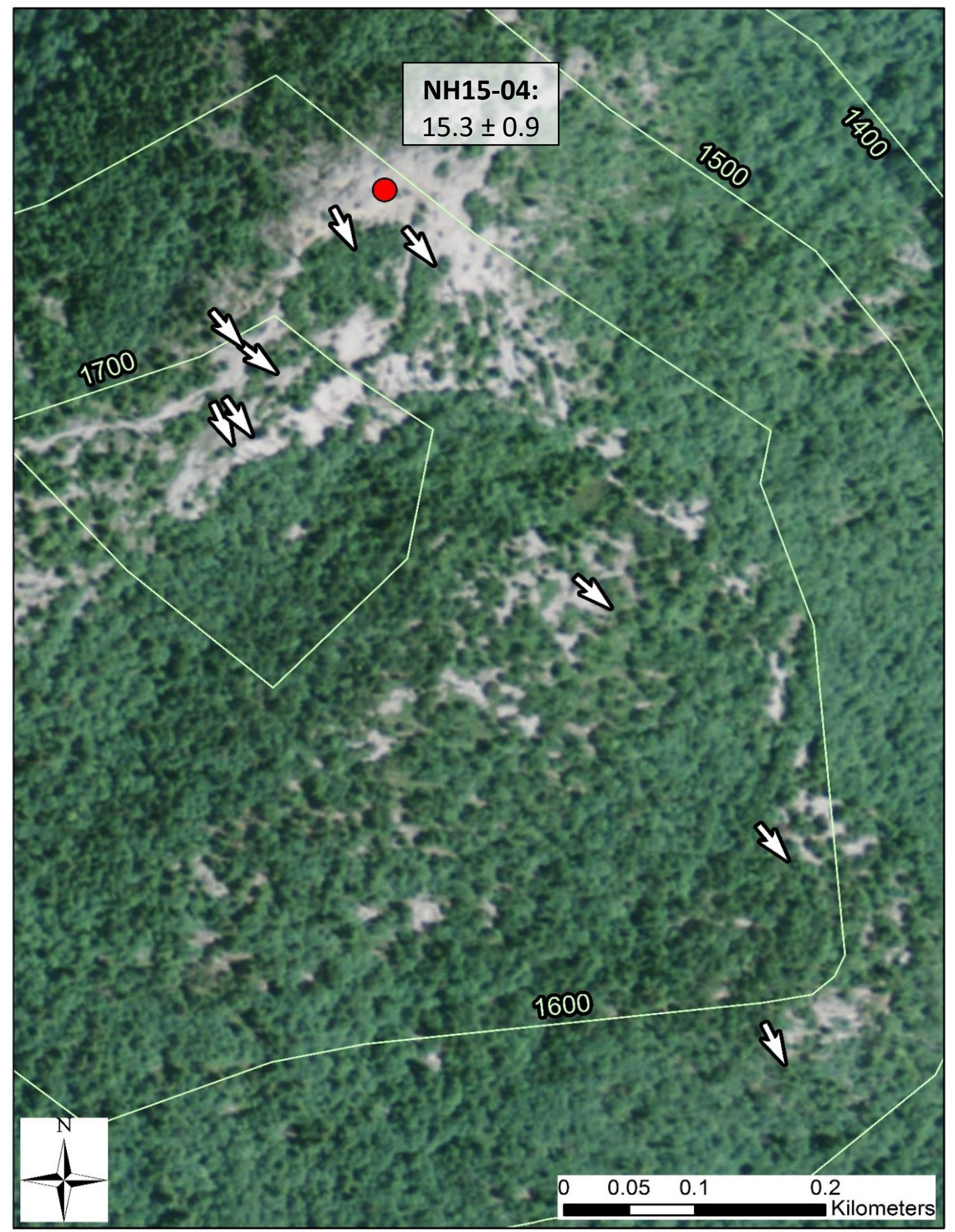

Figure $8 b$ ) Field map showing individual exposure ages and associated external errors on Mt. Major. Striations measurements are shown as white arrows. (Source data NH GRANIT) 


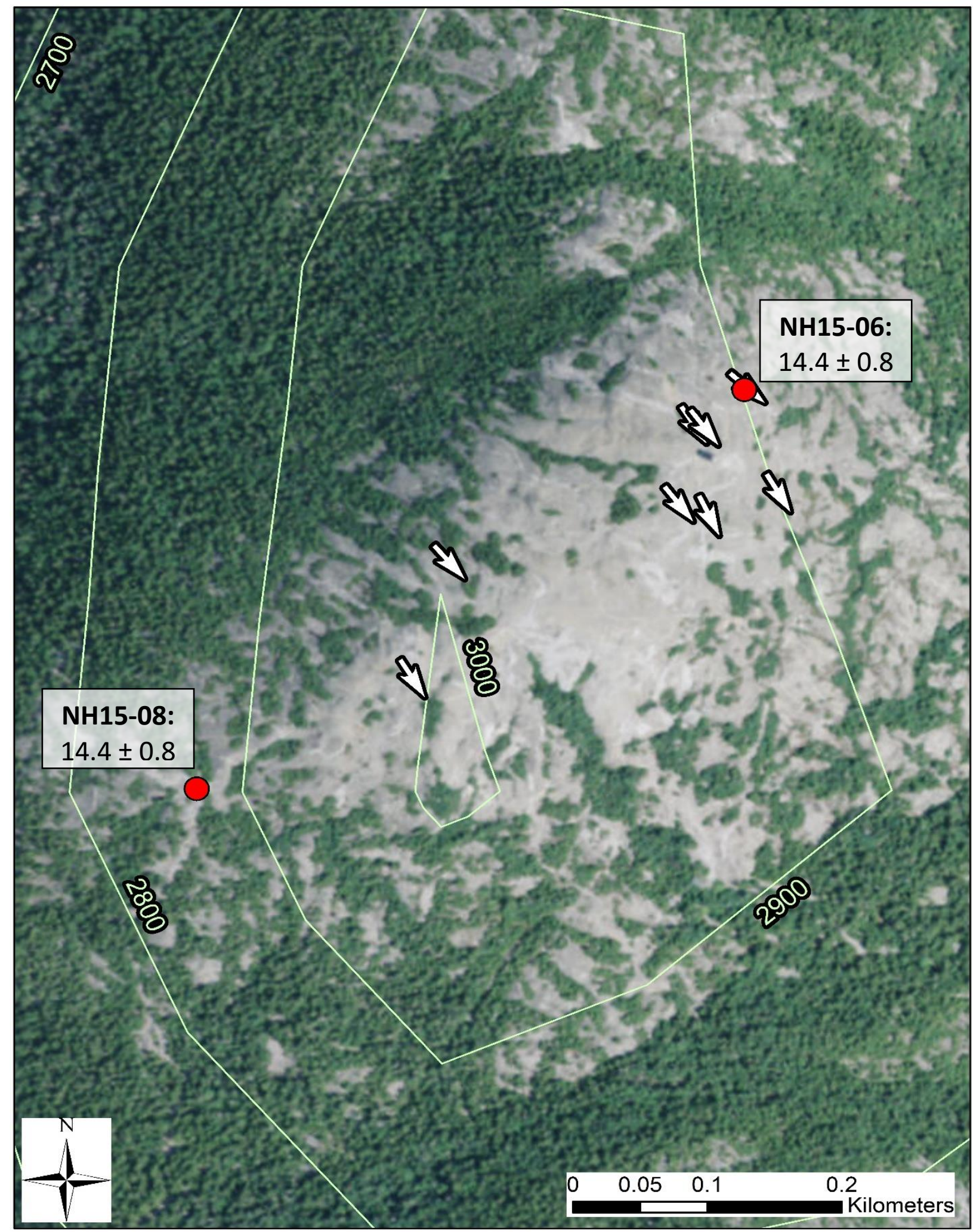

Figure 8c) Field map showing individual exposure ages and associated external errors on Mt. Cardigan. Striations measurements are shown as white arrows. (Source data NH GRANIT) 


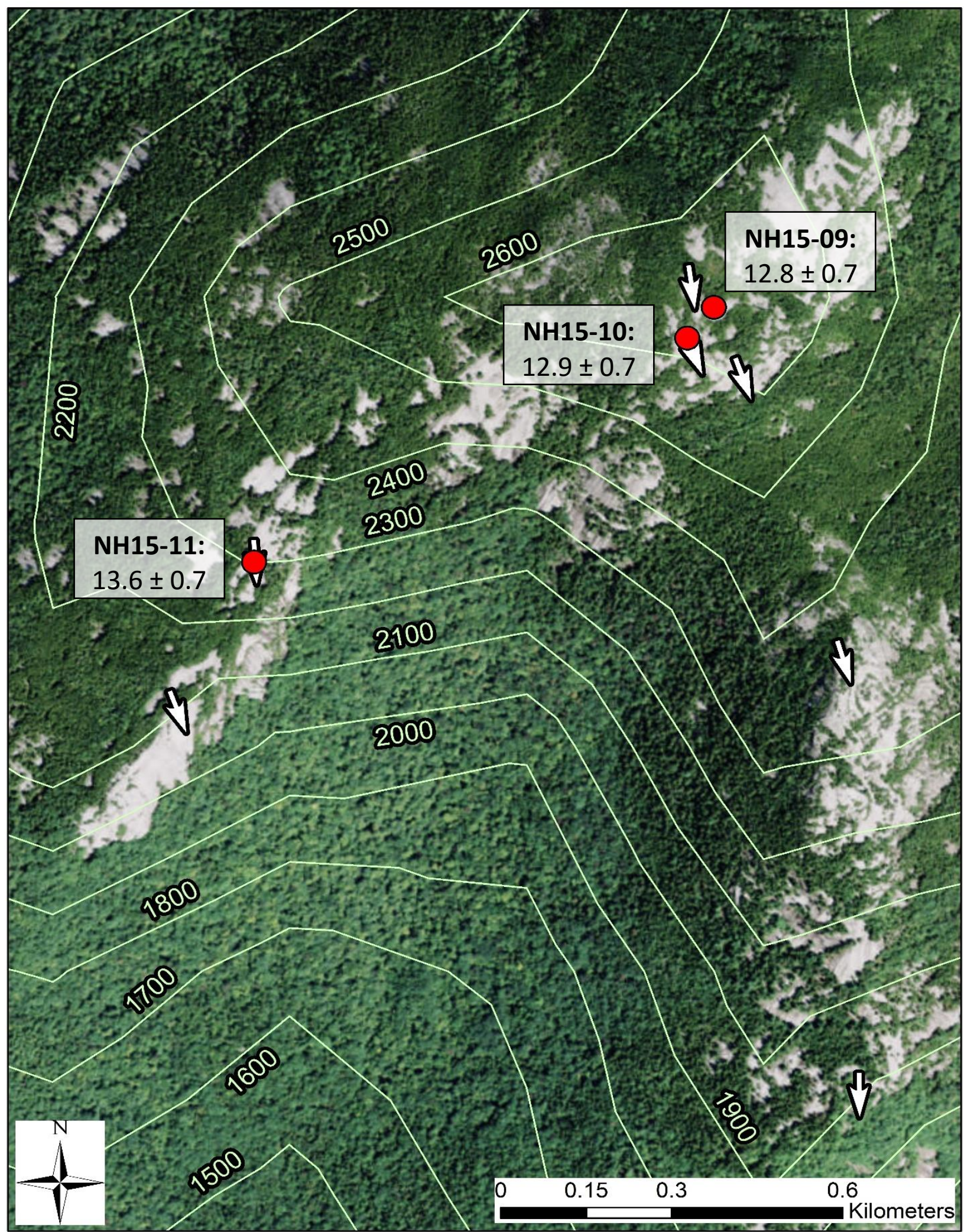

Figure 8d) Field map showing individual exposure ages and associated external errors on Mt. Dickey. Striations measurements are shown as white arrows. (Source data NH GRANIT) 


\section{$\underline{3.2 \text { Ice Flow Patterns }}$}

Striations mapped in this study (Table 2) were used to inform ice profile reconstructions. Mean ice flow through New Hampshire during the LGM was south-southeast $\left(145^{\circ}\right)$ but ranged from $90^{\circ}-210^{\circ}$ as indicated by striations mapped by Hitchcock (1878). The 100 striations found at the highest elevations in New Hampshire (blue arrows in Figure 9) display a mode ice flow of roughly $145^{\circ}$, seen in Figure 8, but range from $105^{\circ}-195^{\circ}$. The 100 striations associated with the lowest elevations (red arrows in Figure 9) present two distinct ice flow patterns. The first dominant ice flow pattern trend equates to the mode of all the measurements at $145^{\circ}$, similar to that of the highest elevation striations. The second and slightly less dominant ice flow pattern has a mode of $170^{\circ}$ when sampling from striations between $165-210^{\circ}$ as seen in Figure 10.

However, the azimuthal range of striations found at lower elevations varies from $90-210^{\circ}$.

\begin{tabular}{|c|c|c|c|}
\hline Location & $\begin{array}{l}\text { Latitude } \\
\text { (DD) }\end{array}$ & $\begin{array}{l}\text { Longitude } \\
\text { (DD) }\end{array}$ & $\begin{array}{c}\text { Azimuthal Direction } \\
\left({ }^{\circ} \text { from } N\right)\end{array}$ \\
\hline \multirow[t]{8}{*}{ Cardigan } & 43.6496 & -71.91428 & 148 \\
\hline & 43.6497 & -71.91435 & 139 \\
\hline & 43.6494 & -71.91378 & 132 \\
\hline & 43.6492 & -71.91425 & 142 \\
\hline & 43.6493 & -71.91445 & 154 \\
\hline & 43.6499 & -71.91399 & 149 \\
\hline & 43.6490 & -71.91598 & 147 \\
\hline & 43.6484 & -71.91622 & 143 \\
\hline \multirow[t]{7}{*}{ Dickey } & 43.9139 & -71.57574 & 179 \\
\hline & 43.9191 & -71.57598 & 163 \\
\hline & 43.9225 & -71.57757 & 160 \\
\hline & 43.9236 & -71.57838 & 172 \\
\hline & 43.9228 & -71.57835 & 158 \\
\hline & 43.9203 & -71.58526 & 176 \\
\hline & 43.9185 & -71.58648 & 159 \\
\hline \multirow[t]{4}{*}{ Major } & 43.5092 & -71.28501 & 154 \\
\hline & 43.5103 & -71.28502 & 141 \\
\hline & 43.5116 & -71.28625 & 132 \\
\hline & 43.5134 & -71.28745 & 142 \\
\hline
\end{tabular}




\begin{tabular}{|cccc}
\hline Major & 43.5135 & -71.28796 & 153 \\
\cline { 2 - 4 } & 43.5128 & -71.28855 & 140 \\
\cline { 2 - 4 } Monadnock & 43.5129 & -71.28877 & 120 \\
\cline { 2 - 4 } & 43.5125 & -71.28869 & 145 \\
\cline { 2 - 4 } & 43.5124 & -71.28880 & 175 \\
\hline & 42.8565 & -72.10963 & 112 \\
\hline 42.8566 & -72.10951 & 156 \\
\hline 42.8644 & -72.11129 & 173 \\
\hline 42.8611 & -72.10823 & 150 \\
\hline 42.8616 & -72.10565 & 159 \\
\hline & 42.8616 & -72.10208 & 104 \\
\hline
\end{tabular}

Table 2: Striation measurement data from each field site including: geographic location and azimuthal direction. Measurements reported for Mt. Monadnock were collected by Billings (1949).

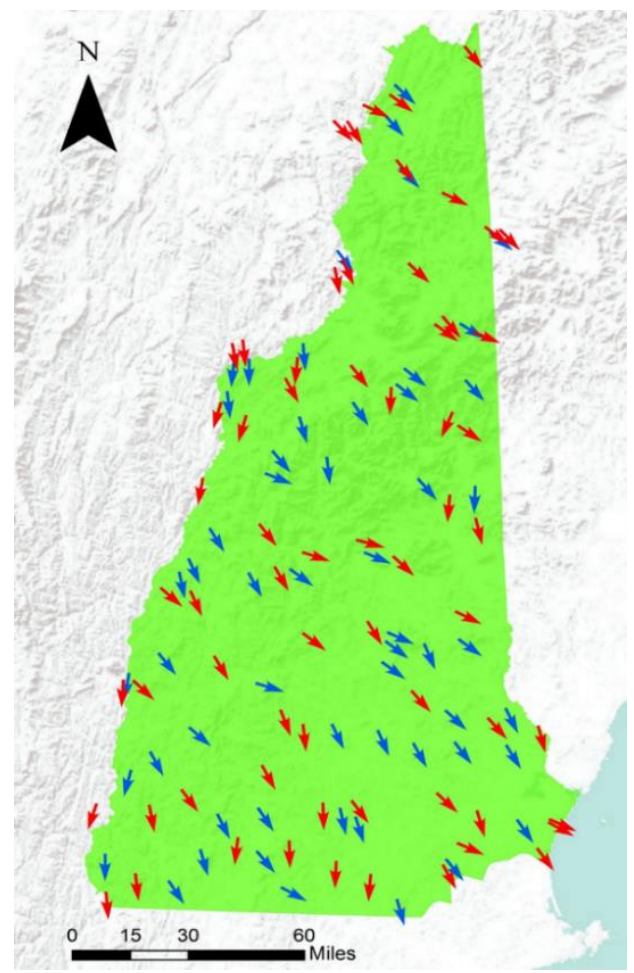

Figure 9: Map displaying striation patterns in New Hampshire. Red arrows indicate lowest elevation striation in each equal area grid cell, and blue arrows indicate the highest elevation striation from each grid cell. (Source data: NH GRANIT and Hitchcock, 1878)

\section{Highest Striations}
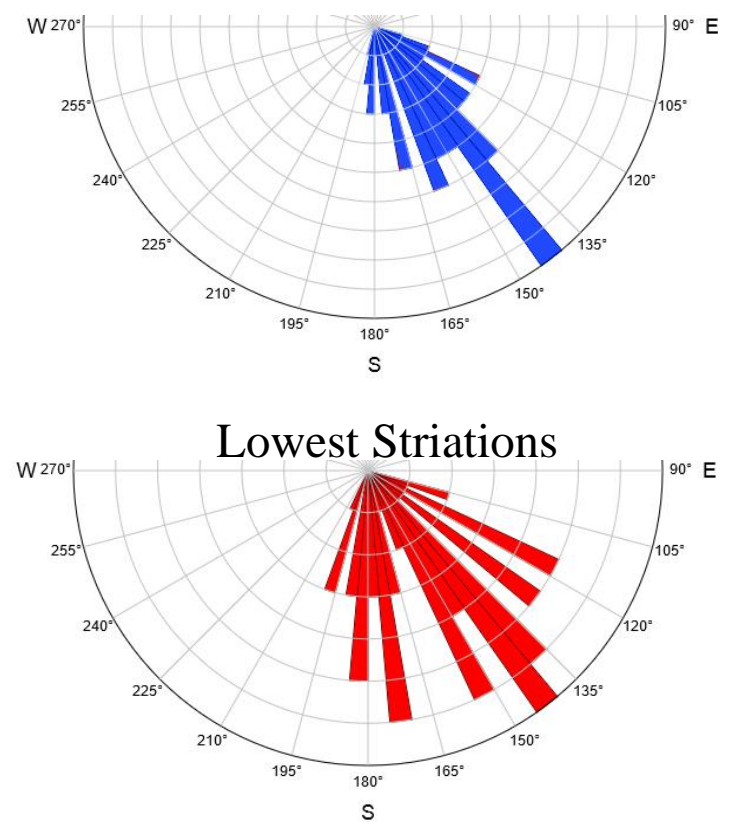

Figure 10: Corresponding rose petal diagrams with azimuthal distributions of highest and lowest elevation striations in New Hampshire. (Source data: NH GRANIT and Hitchcock, 1878) 


\section{Chapter IV: Discussion and Interpretations}

\section{1: Comparison of ${ }^{10} \mathrm{Be}$ ages from sample summits}

The mean exposure age of each summit is interpreted as the best representation for the timing of deglaciation. However, several factors can affect the apparent age of exposure for each peak, including inheritance of cosmogenic nuclides, post-glacial erosion, and shielding. Nuclide inheritance can occur when ice is not erosive enough to scour away nuclides produced during prior exposure, thereby increasing the exposure age. Post-glacial erosion can cause apparent ages to be much younger than the true age of exposure, as erosion scours the surface removing

${ }^{10} \mathrm{Be}$ and decreasing the overall ${ }^{10} \mathrm{Be}$ concentration. Finally, various types of shielding caused by topography, snow cover, or tree canopies can lead to younger ${ }^{10} \mathrm{Be}$ exposure ages. Corrections to topographic shielding can be made based on documentation of individual field sites.

On Mt. Monadnock, all samples were collected from the summit where high winds are likely minimize snow cover during the winter months. All samples were collected from surfaces that display abundant striae and glacial polish indicating there is little post-glacial erosion that has occurred. The three ages from this summit all agree within the internal uncertainty. Similar to Monadnock, the sample from Mt. Major was collected from the exposed summit where effects of snow cover attenuation should be minimized. The sample also has an original ice sculpted surface still present indicating minimal effects of post-glacial erosion. This age compares well with ${ }^{10} \mathrm{Be}$ ages of other summits and is consistent with ice recession from south to north. On Mt. Cardigan sampling was conducted in the same manner as Mts. Major and Monadnock to minimize effects of erosion and shielding. The two ages from Mt. Cardigan are indistinguishable 
from each other. On Mt. Dickey, the two ages on the summit agree within the internal error but are approximately 0.7 ka younger than the sample collected from a lower elevation.

The summit of Mt. Dickey is partially covered with a coniferous tree canopy (covering $\sim 30 \%$ of the summit), while the collection site $100 \mathrm{~m}$ below the summit is on an exposed ridgeline where there are currently no trees. The ages are likely not altered by post-glacial erosion as the samples still had abundant polish and striations indicating negligible postglacial erosion. One possible influence on these younger ages is that there is currently more tree cover on the summit, which can lower the production rate of ${ }^{10} \mathrm{Be}$. Plug et al. (2007) modeled cosmic ray fluxes through varying canopy types and found that for surfaces in forested regions the net flux is only $1.5 \%$ lower than non-forested regions. Including this correction for Mt. Dickey, the samples from the summit would only increase the exposure age by roughly $0.2 \mathrm{ka}$, which alone is not enough to explain the younger age. Tree cover was once present on the summits of Mts. Monadnock and Cardigan, but was removed in the 1800's due to forest fires (Mansfield, 2006; NHStateParks.org).

Tree cover may have a small impact on production rates, but annual snow cover can have a larger impact on calculated ages. Assuming snow is present on the summits for several months each year, a snow cover correction can be made from Gosse and Phillips (2001) using snow thickness. With an average snow cover of 1 meter for 4 months out of each year and a snow density of $0.4 \mathrm{~g} / \mathrm{cm}^{3}$, a correction of $\sim 4 \%$ is calculated. Applying this correction on the average age for each summit would increase the ages slightly, but would not impact the overall chronology. 


\section{2: Comparison to Previously Reported Chronology:}

To determine if the ${ }^{10} \mathrm{Be}$ ages derived from this study are consistent with the previously documented ice retreat chronology, these ages have been plotted together with the ${ }^{14} \mathrm{C}$ ages in ArcMap (Fig. 11). On their own the ${ }^{10}$ Be ages from this study are consistent with a chronology indicative of ice recession to the north. When compared to the previously established chronology, there are also many consistencies. The average ages from Mts. Monadnock, Major, and Cardigan are all older than ${ }^{14} \mathrm{C}$ isochrones from low lying valleys (Ridge, 2003) at similar latitudes, indicating they were exposed prior to surrounding areas at lower elevation. This result would be expected as ice retreats and thins simultaneously, exposing areas of higher elevation first. The individual ages from the summit of Mt. Dickey are both younger than the ${ }^{14} \mathrm{C}$ ages from varve records or from the basal ${ }^{14} \mathrm{C}$ ages from lake and bog sediment cores even within the external uncertainty of the ${ }^{10} \mathrm{Be}$ ages. The lower sample from Mt. Dickey is also younger than the previously established chronologies, but fits within the $1 \sigma$ uncertainty of the ${ }^{10} \mathrm{Be}$ age. There are some potential difficulties that arise when comparing the ${ }^{10} \mathrm{Be}$ ages to the previously documented ${ }^{14} \mathrm{C}$ ages, most notably with the ${ }^{14} \mathrm{C}$ isochrones from Ridge (2003). In Figure 2 there are no errors reported associated with the ${ }^{14} \mathrm{C}$ ages used to construct the varve chronology, which makes it difficult to discern age uncertainties in in the varve record when comparing to the ${ }^{10} \mathrm{Be}$ ages. 


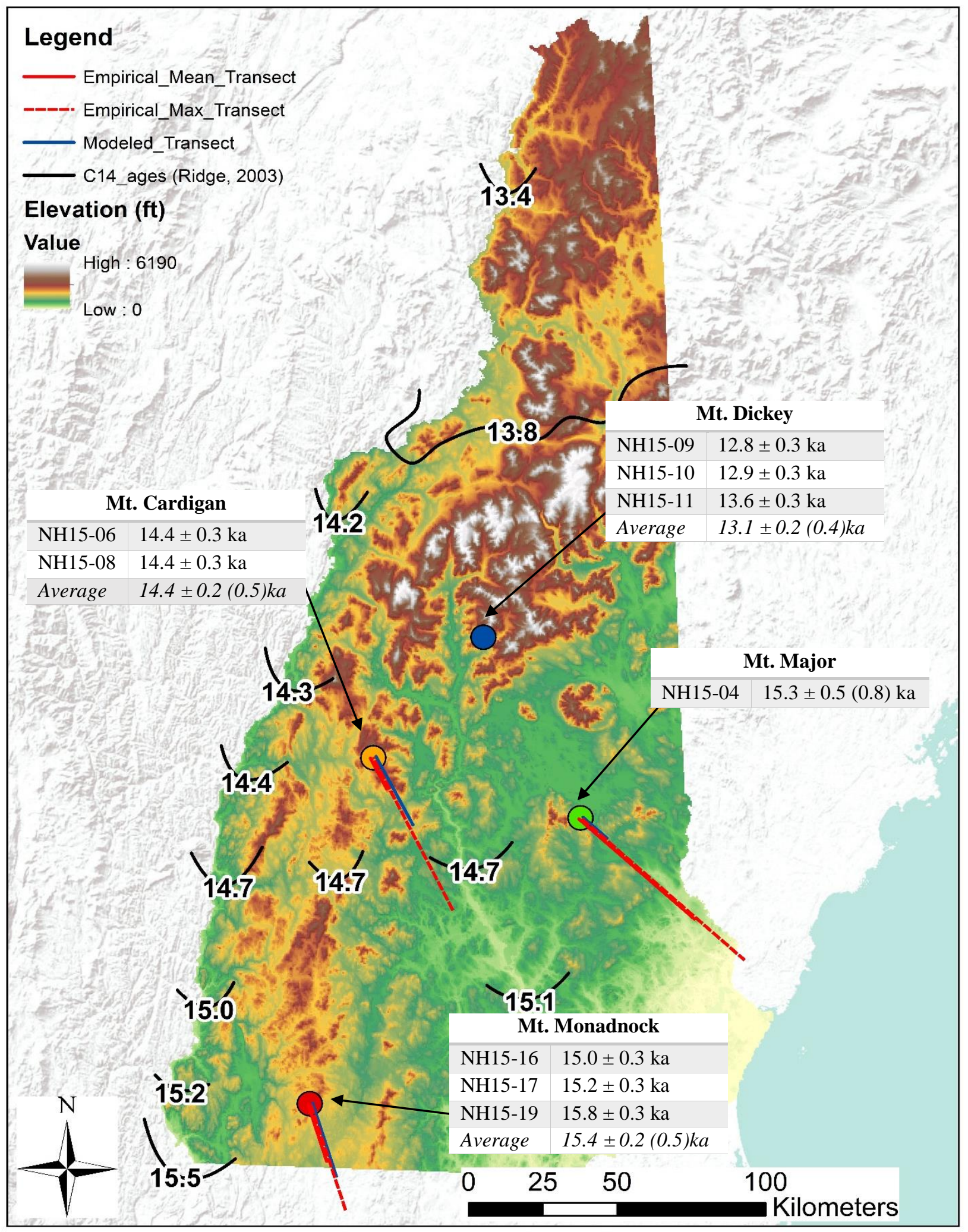

Figure 11: Map of ${ }^{10} \mathrm{Be}$ exposure with average internal and (external) uncertainties from each summit plotted with ${ }^{14} \mathrm{C}$ varve chronology from Ridge (2003). Ice profile transects are plotted from Mts. Cardigan, Major, and Monadnock and correspond to the profiles shown in Figure 12. 
In a study by Bierman et al. (2015), ${ }^{10} \mathrm{Be}$ ages sampled from some of the highest peaks in New England were up to tens of thousands of years older than the LGM. All of the peaks from that study were once inundated with ice, indicated by erratics and striations that can be found on or near all of the summits. The authors determined nuclide inheritance was likely the reason for older ages. In situ cosmogenic ${ }^{14} \mathrm{C}$ ages of $12.7 \pm 2.8$ and $11.0 \pm 2.2$ were processed from Mts. Washington and Katahdin and are consistent with the timing of deglaciation for the LGM when including the $2 \sigma$ uncertainty (Bierman et al., 2015). ${ }^{10} \mathrm{Be}$ has a half-life of 1.4 my compared to 5.7 kyr for ${ }^{14} \mathrm{C}$ and therefore any inherited ${ }^{14} \mathrm{C}$ from exposure prior to glaciation would have decayed away by the time of deglaciation (Bierman et al., 2015). This indicates that nuclide inheritance of ${ }^{10} \mathrm{Be}$ was likely the cause for the older than expected ages, indicating that the ice on these peaks was not erosive enough to scour away the pre-exposed surface. Ice sheets are much thinner on topographic highs, which can result in cold-based ice that is weakly erosive, even at temperate latitudes (Bierman et al., 2015).

Samples collected from the lower summits in central and southern New Hampshire provide ${ }^{10} \mathrm{Be}$ exposure ages that fit closely with the previously documented retreat chronology (Ridge, 2003; 2004) and therefore indicate the ice was likely erosive enough to remove any nuclides accumulated during prior exposure. The ice would have been almost $1 \mathrm{~km}$ thicker over these lower peaks than the summit of Mt. Washington, enabling more geothermal heat to be trapped and creating more friction between the glacier sole and bedrock surface. This suggests a scenario of warm based ice and efficient subglacial quarrying and abrasion on lower elevation peaks in New Hampshire. 


\section{3: Ice Flow Patterns:}

The results from the highest and lowest elevation ice flow measurements demonstrate that ice flow patterns shifted as the LIS thinned and became topographically confined. The highest elevation striations display the direction of regional ice flow for the LIS $\left(\sim 145^{\circ}\right)$, as they are measured from areas where there are no topographic barriers and therefore ice would have been able to flow unobstructed from major ice divides. The results from the highest elevation striations show the mode of striations between $140-145^{\circ}$, which fits well with the known trend of regional ice flow for the LIS. The lowest elevation striations display a much wider range of striation patterns than those found at the highest elevation. While there is still a large proportion of striations trending $135-145^{\circ}$, the overall distribution is much more scattered. There is another clustering of ice flow measurements between $170-185^{\circ}$ which is well-aligned with the orientation of many of New Hampshire's major river valleys and notches including the Connecticut River and Merrimack River valleys, Franconia Notch and Mt. Washington Valley. These distributions show that as the LIS thinned and retreated the ice became topographically confined and ice flow patterns shifted to follow the orientation of the valleys in which they were constrained. This provides evidence supporting the second hypothesis by Wright (2015), that cross cutting striations are caused by topographic constraints and not by ice sheet readvance.

\section{4: Ice Sheet Profiles}

In order to generate ice sheet profiles anchored to each sampled mountain, the striation patterns were used in order to determine the transect direction (Fig. 11). No ice sheet profile was generated for Mt. Dickey because the ages do not fit well with the regional ice retreat chronology. The modeled ice sheet profiles resulting from Equation 1 (Nye, 1951); blue lines in 
Figure 12 were compared to empirically derived profiles that were drawn between the dated summit of each mountain and independently dated ice margins of similar age to the south (solid red lines in Fig. 12). The red dashed lines in Figure 12 represent the maximum possible extent of the empirical mean profiles when including the maximum $1 \sigma$ uncertainty in ${ }^{10} \mathrm{Be}$ ages from peaks in this study. Minimum-extent indicators that subtract the $1 \sigma$ uncertainty from the average age of each summit are not displayed because they cannot be reconciled with dated ice marginal features. The modeled ice sheet profiles for Mts. Cardigan, Major, and Monadnock all fit within the maximum extents of the empirical profiles. The error associated with the varve ages is difficult to quantify and was not taken into account with the ice sheet profiles. Since the modeled ice sheet profiles fits well within the constraints of all the sampled summits, the peak emergence ages are consistent with what would be predicted by drawing glaciologically-derived surface profiles from independently dated ice margins.

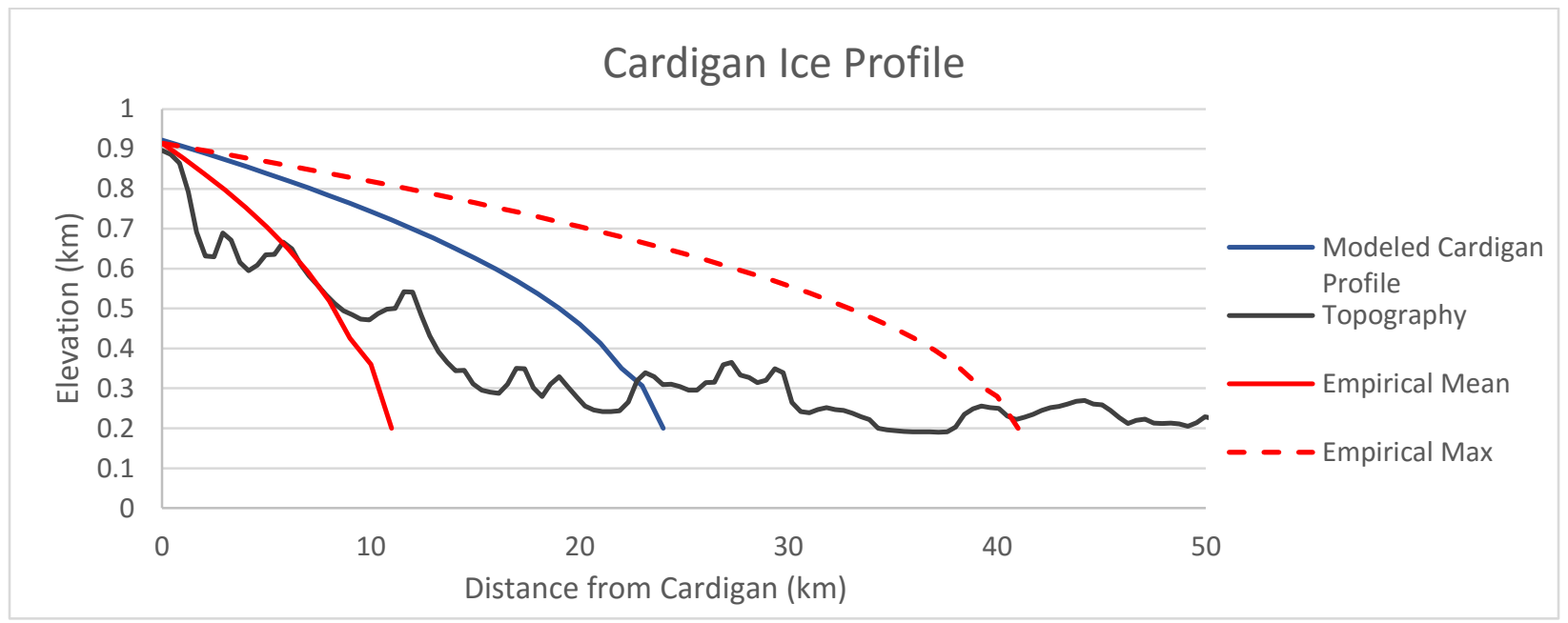



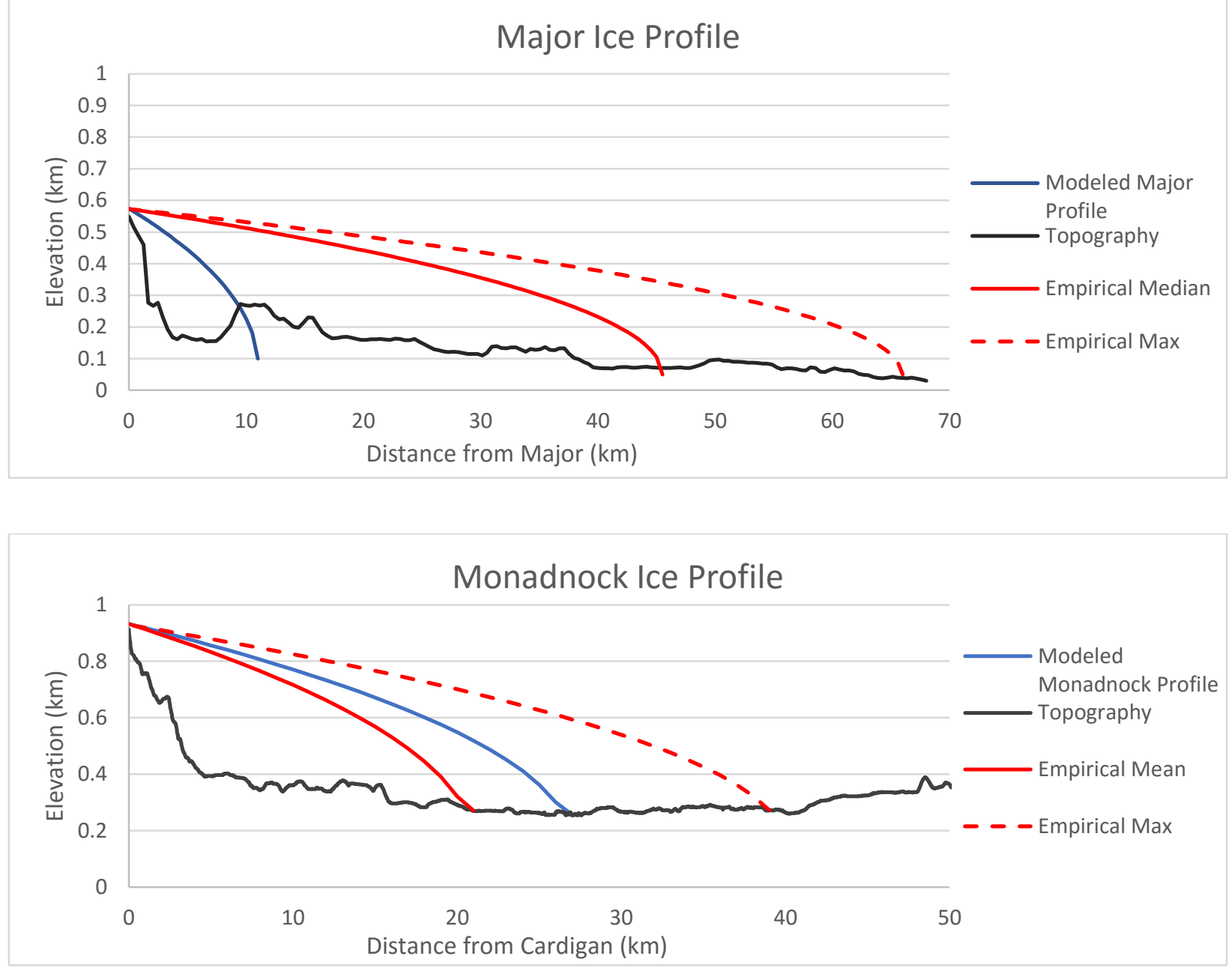

Figure 12: Modeled ice sheet profiles from Mts. Cardigan, Major, and Monadnock. Blue lines indicate the modeled profile results calculated using Equation 1. Solid red lines show the mean-dataconstrained ice sheet profiles and dashed red lines show the maximum-data-constrained ice sheet profile. Minimum-data-constrained ice sheet profiles are not depicted, as they would fall north of the sample summits.

\section{5: Ice Sheet Surface Models}

To estimate possible thinning rates of the LIS, the modeled ice sheet profile equation (Nye, 1952) was used to generate three-dimensional ice sheet surfaces across the entire state of New Hampshire. By interpolating between transects of the modeled ice profiles anchored to the dated recessional features, ice surfaces were generated to reconstruct a regional view of ice 
thinning through time (Fig. 13). The modeled ice surfaces were tied into dated ice margins

rather than the ${ }^{10} \mathrm{Be}$ ages from the peaks because the ice margin chronology spans a longer period of time in which to produce ice surfaces. The amount and rate of ice thinning over each peak was determined from the model predicted ice thickness over each summit and the timing of peak emergence. This method was applied to all three sampled summits during each modeled time interval, and the site specific mean thinning rates at each peak were used to define broader regional thinning rates. The modeled ice sheet surfaces show each summit emerging at a time that is consistent with the average ${ }^{10} \mathrm{Be}$ age of each summit with the exception of Dickey. Changes in topography due to isostatic rebound were not taken into account as they are negligible for the timescale discussed in this study.

Modeled ice sheet surfaces were also compared against previously acquired exposure ages from Bierman et al. (2015). The reconstructed ice sheet surfaces show Mt. Washington emerging from the thinning LIS at roughly $15.2 \mathrm{ka}$. This age is consistent within the uncertainty of the in situ cosmogenic ${ }^{14} \mathrm{C}$ age of $12.7 \pm 2.8$ ka from Bierman et al. (2015).

\section{6: Paleoclimatic Implications}

The estimated ice sheet thinning rates, while broadly determined by modeled ice sheet surfaces and ${ }^{10} \mathrm{Be}$ ages, provide valuable insight on changes in surface geometry of the LIS through time. Between $15.8 \mathrm{ka}$ and 15.5 ka modeled ice sheet surfaces in New Hampshire indicate a thinning rate of roughly $1.0 \mathrm{~m} / \mathrm{yr}$. From $15.5-15.2 \mathrm{ka}$ ice thinning rates continued at a rate of $1.0 \mathrm{~m} / \mathrm{yr}$, however after $15.2 \mathrm{ka}$ thinning rates double to roughly $2.0 \mathrm{~m} / \mathrm{yr}$. Work done by Ridge et al. (2012) found that ice margin retreat rates increased around $15.0 \mathrm{cal}$ ka, which coincides with the onset of increased thinning from the modeled ice surfaces in this study. Ridge 

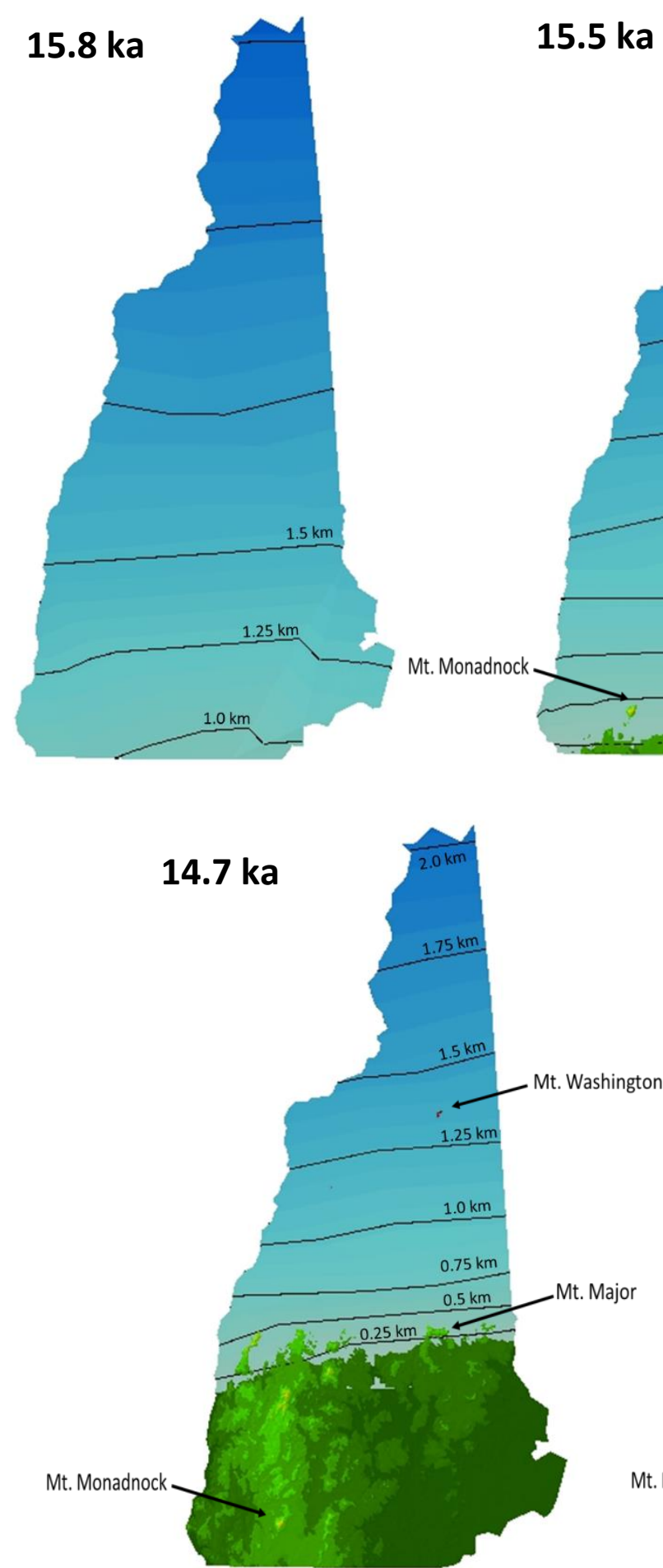
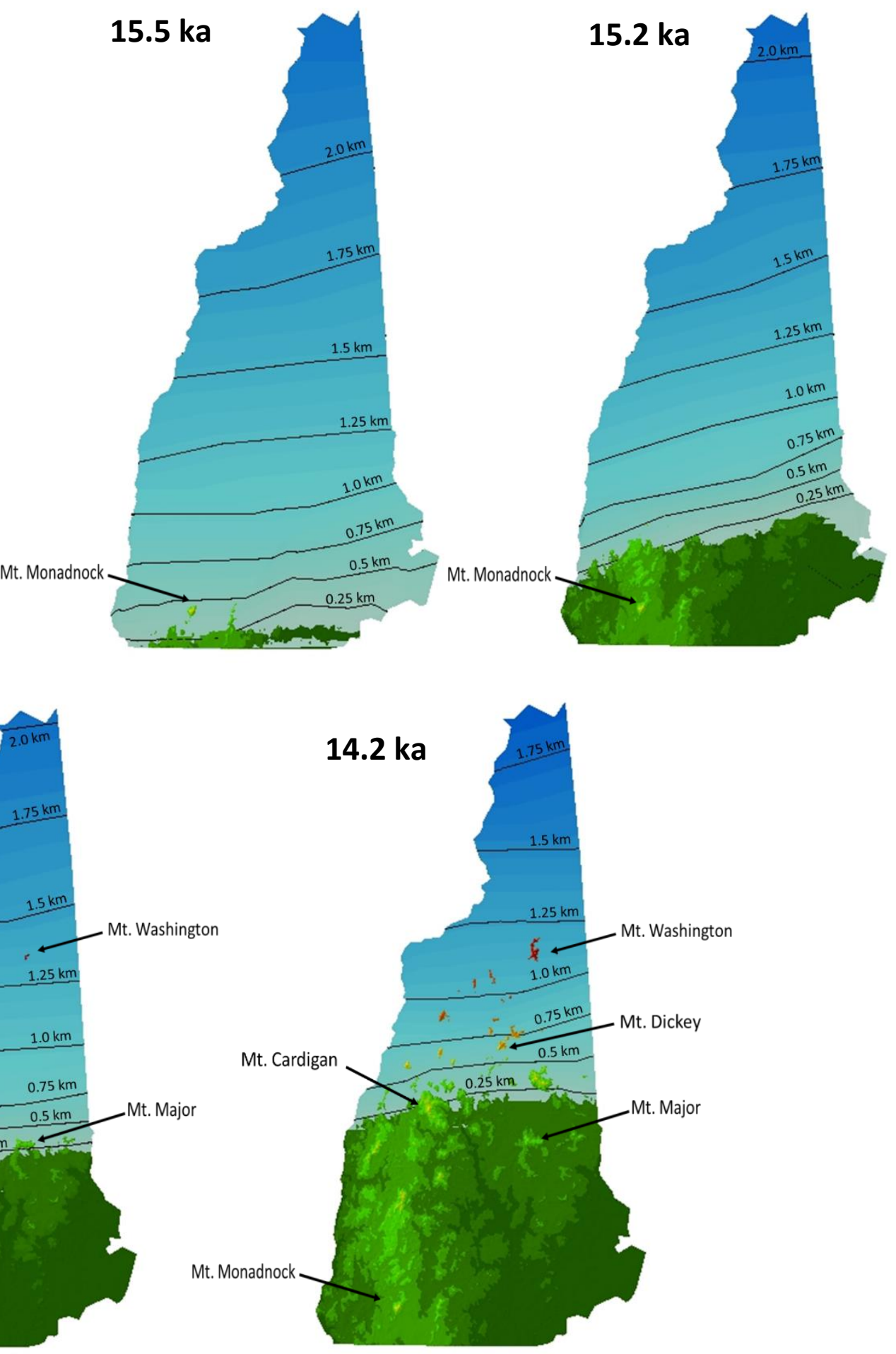

Figure 13: Modeled ice sheet surfaces between 15.8-14.3 ka. Darker blues indicate thicker portions of the modeled ice sheet. Topography during ice retreat is shown in a gradational color ramp with darker greens at lower elevations and red indicating the highest elevations. 
et al. (2012) correlated varve thickness with regional and global climatic events recorded in Greenland ice cores. A notable temperature increase occurs in the ice core record between 15.0 cal ka and 13.8 cal ka during the Bølling Allerød (Rasmussen et al., 2006), which is in line with the increased rates of margin retreat (Ridge et al., 2012) and ice surface lowering documented in this study. The ice sheet surfaces are tied to the North American Varve Chronology sites and are therefore directly linked to the recession rates. While large ice sheets typically take significant periods of time to respond to climatic changes, other studies have shown that ice sheet margins can respond to changes in climate on decadal timescales depending on ice flow characteristics or presence of calving margins (Thomas and Briner, 2009; Young et al., 2013). 


\section{CHAPTER V: CONCLUSIONS}

${ }^{10} \mathrm{Be}$ ages determined from four summits in central and southern New Hampshire provide one of the first reconstructions of ice-surface lowering across the region. The average ${ }^{10} \mathrm{Be}$ ages from this study fit within the ice recession chronology documented by Ridge (2003) with the exception of Mt. Dickey. Ice flow patterns, paired with ${ }^{10} \mathrm{Be}$ ages and previously documented radiocarbon ages define empirical ice sheet profiles that match modeled ice sheet profiles derived from standard ice dynamics variables further strengthening the confidence in the ${ }^{10} \mathrm{Be}$ ages. The ${ }^{10} \mathrm{Be}$ ages suggest that the LIS was erosive enough to remove any nuclides produced during prior exposure from the lower summits in New Hampshire, unlike ice on Mt. Washington and other high peaks where the overriding glacier may have been cold-based and weakly erosive. Combined ice flow measurements documented from both this study and from Hitchcock (1878) suggest that striations found at the highest elevations in the region display unobstructed ice flow aligned with the broad regional ice flow pattern. Lower elevation striation measurements suggest that as the LIS thinned and retreated, ice became confined to low lying valleys possibly causing cross-cutting striation patterns to form in these regions similar to results documented by Wright (2015) in Vermont.

Reconstructed ice surfaces projected north of dated ice margins using glaciological principles depict an uptick in ice thinning rates at 15.2 from $1 \mathrm{~m} / \mathrm{yr}$ to $2 \mathrm{~m} / \mathrm{yr}$ that coincides with the increased rate of margin retreat documented by Ridge et al (2012). This acceleration in thinning and margin retreat coincides with the start of the Bølling Allerød period in the North Atlantic region. The ${ }^{10} \mathrm{Be}$ ages from this study fill a large gap in the chronology of ice recession in New England and provide novel insight on how the LIS may have responded to climatic changes during the last deglaciation. 


\section{REFERENCES}

Agassiz, L., 1870. On the former existence of local glaciers in the White Mountains. American Association for the Advancement of Science, Proceedings, 19: 161-167 (also in American Naturalist, 4: 550-558, 1870).

Antevs, E., 1922. The recession of the last ice sheet in New England. American Geographical Society, Research Series 11, 120 p. and 6 pl.

Antevs, Ernst, 1928, The last glaciation, with special reference to the ice sheet in northeastern North America: American Geographical Society Research Series, no. 17, 292 p.

Balco, G., Briner, J., Finkel, R. C., Rayburn, J. A., Ridge, J. C., \& Schaefer, J. M. 2009. Regional beryllium-10 production rate calibration for late-glacial northeastern North America. Quaternary Geochronology, 4(2), 93-107.

Balco, G., Stone, J., Lifton, N., Dunai, T., 2008. A simple, internally consistent, and easily accessible means of calculating surface exposure ages and erosion rates from Be-10 and Al-26 measurements. Quat. Geochronol. 3, 174-195.

Balco, G., Stone, O.H., Porter, S.C., Caffee, M.W. 2002. Cosmogenic-nuclide ages for New England coastal moraines, Martha's Vineyard and Cape Cod, Massachusetts, USA. Quaternary Science Reviews, 21; 2127-2135.

Benn, D. I., \& Evans, D. J. 2010 Glaciers \& glaciation. London: Hodder Education.

Benn, D. I., \& Hulton, N. R. 2010. An Excel TM spreadsheet program for reconstructing the surface profile of former mountain glaciers and ice caps. Computers \& Geosciences, 36(5), 605610.

Bierman, P. R., Davis, P. T., Corbett, L. B., Lifton, N. A., \& Finkel, R. C. 2015. Cold-based Laurentide ice covered New England's highest summits during the Last Glacial Maximum. Geology, 43(12), 1059-1062.

Billings, K. 1949. Geology of the Monadnock region of New Hampshire. Geological Society of America Bulletin, 60(8), 1249-1280.

Borchers, B., Marrero, S., Balco, G., Caffee, M., Goehring, B., Lifton, N., \& Stone, J. 2016. Geological calibration of spallation production rates in the CRONUS-Earth project. Quaternary Geochronology, 31, 188-198.

Bromley, G. R., Hall, B. L., Thompson, W. B., Kaplan, M. R., Garcia, J. L., \& Schaefer, J. M. 2015. Late glacial fluctuations of the Laurentide Ice Sheet in the White Mountains of Maine and New Hampshire, USA. Quaternary Research, 83(3), 522-530. 
Clark, P. U., Dyke, A. S., Shakun, J. D., Carlson, A. E., Clark, J., Wohlfarth, B., McCabe, A. M. 2009. The last glacial maximum. Science, 325(5941), 710-714.

doi:http://dx.doi.org/10.1126/science.1172873

Creasy, J. W. and Eby, G. N. 1993 Ring dikes and plutons: A deeper view of calderas as illustrated by the White Mountain igneous province, New Hampshire. In Cheney, J. T. and Hepburn, J. C. (eds.) Field Trip Guidebook for the Northeastern United States: 1993 Boston GSA, Vol. 1. Contribution No. 67, Department of Geology and Geography, University of Massachusetts, Amherst, MA, pp. N1-N25.

Cuffey, K. M., \& Patterson, W. S. 2010. The physics of glaciers (4th ed). Burlington, MA: Butterworth-Heinemann/Elsevier.

Davis, P. T., Bierman, P. R., Corbett, L. B., \& Finkel, R. C. 2015. Cosmogenic exposure age evidence for rapid Laurentide deglaciation of the Katahdin area, west-central Maine, USA, 16 to 15 ka. Quaternary Science Reviews, 116, 95-105.

Davis, P. T., \& Davis, R. B. (1980). Interpretation of minimum-limiting radiocarbon dates for deglaciation of Mount Katahdin area, Maine. Geology, 8(8), 396-400.

Davis, R. B. and Jacobson, G. L., Jr., 1985. Late-glacial and early Holocene landscapes in northern New England and adjacent areas of Canada. Quaternary Research, 23: 341-368.

Doll, C.G., Stewart, D.P., and MacClintock, Paul, 1970, Surficial Geologic Map of Vermont: Vermont Geological Survey, Miscellaneous Map MISCMAP-02, scale 1:250,000

Dyke, A. S., Andrews, J. T., Clark, P. U., England, J. H., Miller, G. H., Shaw, J., \& Veillette, J. J. 2002. The Laurentide and Innuitian ice sheets during the last glacial maximum. Quaternary Science Reviews, 21(1), 9-31.

Flint, R.F., 1957. Glacial and Pleistocene Geology. John Wiley and Sons, New York, 553 p.

Goldthwait, J. W., 1916. Glaciation in the White Mountains of New Hampshire. Geological Society of America Bulletin, 27: 263-294.

Goldthwait, J.W., Goldthwait, L. and Goldthwait, R.P., 1951. The geology of New Hampshire: Part 1-surficial geology. New Hampshire State Planning and Development Commission, Concord, 81 p. and map.

Gosse, J. C., \& Phillips, F. M. 2001. Terrestrial in situ cosmogenic nuclides: theory and application. Quaternary Science Reviews, 20(14), 1475-1560.

GRANIT, 2015. Glacial Point Features in New Hampshire.www.granit.unh.edu/data 
Hitchcock, C. 1878. Composite: New Hampshire topographic, glacial feature map. (ca. 1:154,800.) NH: New York: Julius Bien.

Iversen, J. 1953. Radiocarbon dating of the Alleröd period. Science, 118(3053), 9-11.

Jackson, C. T., 1844. Final report on the geology and mineralogy of the State of New Hampshire, with contributions toward the improvement of agriculture and metallurgy. Carroll \& Baker, State Printers, Concord, 384 p.

Johnson, E.A., Murphy, T., and Torreson, O.W., 1948, Prehistory of the Earth's magnetic field: Terrestrial Magnetism and Atmospheric Electricity (now Journal of Geophysical Research), v. 53, p. 349-372.

Kohl, C. P., and Nishiizumi, K., 1992, Chemical isolation of quartz for measurement of in-situproduced cosmogenic nuclides: Geochimica et Cosmochimica Acta, v. 56, no. 9, p. 35833587.

Lal, D., 1991. Cosmic ray labeling of erosion surfaces: in situ nuclide production rates and erosion models. Earth Planet. Sci. Lett. 104, 424-439.

Larsen, F.D., 1972. Glacial history of Central Vermont. In: Doolan, B.L., Stanley, R.S. (Eds.), New England Intercollegiate Geological Conference Guidebook, vol. 64, pp. 296e316.

Licciardi, J. M., Clark, P. U., Jenson, J. W., \& MacAyeal, D. R. (1998). Deglaciation of a softbedded laurentide ice sheet. Quaternary Science Reviews, 17(4-5), 427-448.

Licciardi, J.M., 2000. Alpine glacier and pluvial lake records of late Pleistocene climate variability in the western United States. Ph.D. Thesis. Corvallis, Oregon State University, 155pp.

Lifton, N., Sato, T., \& Dunai, T. J. 2014. Scaling in situ cosmogenic nuclide production rates using analytical approximations to atmospheric cosmic-ray fluxes. Earth and Planetary Science Letters, 386, 149-160.

Lyons, J. B., Tufts-Moore, S., Koozmin, E. D., Falk, T., \& Mathieux, D. P. 1997. Bedrock geologic map of New Hampshire. The New Hampshire Geological Survey.

Marshall, S. J., Tarasov, L., Clarke, G. K., \& Peltier, W. R. 2000. Glaciological reconstruction of the Laurentide Ice Sheet: physical processes and modelling challenges. Canadian Journal of Earth Sciences, 37(5), 769-793.

Mansfield, H. 2006. Where the mountain stands alone: Stories of place in the Monadnock Region. Hanover: University Press of New England. 
McNish, A.G. and Johnson, E.A., 1938. Magnetization of unmetamorphosed varves and marine sediments. Terrestrial Magnetism and Atmospheric Electricity (now Journal of Geophysical Research), 43: 401-407.

Munroe, J.S., Ryan, P.C., Carlson, H.A., Miller, E.K., 2007. Testing latest Wisconsinan ice flow directions in vermont through quantitative X-ray diffraction analysis of soil mineralogy. Northeast. Geol. Environ. Sci. 29 (4), 263.

NH State Parks. Retrieved June 16, 2016, from http://www.nhstateparks.org/visit/stateparks/cardigan-state-park.aspx

Nye, J. F. (1952). A method of calculating the thicknesses of the ice-sheets. Nature, 169, 529530.

Peltier, W. R. 2004. Global glacial isostasy and the surface of the ice-age Earth: the ICE-5G (VM2) model and GRACE. Annu. Rev. Earth Planet. Sci., 32, 111-149.

Plug, L. J., Gosse, J. C., McIntosh, J. J., \& Bigley, R. 2007. Attenuation of cosmic ray flux in temperate forest. Journal of Geophysical Research: Earth Surface, 112(F2).

Rasmussen, S. O., Andersen, K. K., Svensson, A. M., Steffensen, J. P., Vinther, B. M., Clausen, H. B., Siggaard-Andersen, M.-L., Johnsen, S. J., Larsen, L.B., Dahl-Jensen, D., Bigler, M., Rothlisberger, R. R., Fischer, H., Goto-Azuma, K., Hansson, M. E., and Ruth, U., 2006, A new Greenland ice core chronology for the last termination: Journal of Geophysical Research Atmospheres, v. 111, D06102, http://dx.doi.org/10.1029/2005JD006079

Ridge, J. C., Balco, G., Bayless, R. L., Beck, C. C., Carter, L. B., Dean, J. L., \& Wei, J. H. (2012). The new North American Varve Chronology: A precise record of southeastern Laurentide Ice Sheet deglaciation and climate, 18.2-12.5 kyr BP, and correlations with Greenland ice core records. American Journal of Science, 312(7), 685-722.

Ridge, J. C. and Larsen, F. D., 1990. Re-evaluation of Antevs' New England varve chronology and new radiocarbon dates of sediments from glacial Lake Hitchcock. Geological Society of America Bulletin, 102: 889-899.

Ridge, J. C., \& Toll, N. J. 1999. Are late-glacial climate oscillations recorded in varves of the upper Connecticut valley, northeastern United States? GFF, 121(3), 187-193.

Ridge, J.C., 2003, Chapter 3: The last deglaciation of the northeastern United States: a combined varve, paleomagnetic, and calibrated 14C chronology, in Cremeens, D.L. and Hart, J.P., eds., Geoarchaeology of Landscapes in the Glaciated Northeast: New York State Museum Bulletin 497 , p. $15-45$.

Ridge, J.C., 2010, (February 26, 2015) The North American Glacial Varve Project. Retrieved from http://eos.tufts.edu/varves. 
Sigafoos, R. S., \& Hendricks, E. L. 1969. The time interval between stabilization of alpine glacial deposits and establishment of tree seedlings. GEOL SURV RES 1969, PROF PAP 650-B, P B 89-B 93, 1969. 5 P, 1 FIG, 1 TAB, 9 REF.

Stewart, D.P., MacClintock, P., 1970. Surficial Geologic Map of Vermont: Vermont Geological Survey, Scale 1:250,000.

Stone, J.O., 2000. Air pressure and cosmogenic isotope production. Journal of Geophysical Research 105 (B10), 23753-23759.

Thomas, E. K., \& Briner, J. P. 2009. Climate of the past millennium inferred from varved proglacial lake sediments on northeast Baffin Island, Arctic Canada. Journal of Paleolimnology, 41(1), 209-224.

Thompson, B. 1999. History of research on glaciation in the White Mountains, New Hampshire (USA). Geographie physique et Quaternaire, 53(1); 7-24.

Thompson, B., Fowler, K., Dorion, C. 1999. Deglaciation of the northwestern White Mountains, New Hampshire. Geographie physique et Quaternaire, 53 (1); 59-77.

Wheelock, G. A. 1873. Striae on Mount Monadnock. The American Naturalist, 7(8), 466-470.

Wright, S. F. 2015. Late Wisconsinan ice sheet flow across northern and central Vermont, USA. Quaternary Science Reviews, 129, 216-228.

Young, N. E., Briner, J. P., Rood, D. H., Finkel, R. C., Corbett, L. B., \& Bierman, P. R. 2013. Age of the Fjord Stade moraines in the Disko Bugt region, western Greenland, and the 9.3 and 8.2 ka cooling events. Quaternary Science Reviews, 60, 76-90. 
APPENDIX 


\section{APPENDIX A}

\begin{tabular}{|c|c|c|c|c|c|c|c|c|}
\hline Sample Name & Longitude & Latitude & Elevation & Thickness & {$\left[{ }^{10} \mathrm{Be}\right]$} & \pm & Age & \pm \\
\hline & $(D D)$ & $(D D)$ & (masl) & (cm) & $\begin{array}{c}\text { atoms } \\
g-1\end{array}$ & $\begin{array}{c}\text { atoms } \\
g-1\end{array}$ & (ka) & (ka) \\
\hline \multicolumn{9}{|c|}{ Martha's Vineyard } \\
\hline $\mathrm{PH}-1$ & 41.3567 & 70.7348 & 91 & 4.5 & 123500 & 3700 & 27.7 & 2.6 \\
\hline WR-2 & 41.3937 & 70.6992 & 54 & 2 & 122900 & 3600 & 27.9 & 2.6 \\
\hline WR-3 & 41.3922 & 70.6995 & 54 & 1.5 & 122800 & 4700 & 27.8 & 2.7 \\
\hline WR-4 & 41.3939 & 70.6972 & 30 & 3 & 121800 & 3500 & 28.5 & 2.6 \\
\hline WR-5 & 41.3922 & 70.6983 & 51 & 6 & 102900 & 3000 & 24.2 & 2.2 \\
\hline WR-6 & 41.3897 & 70.7017 & 51 & 4 & 110600 & 4200 & 25.6 & 2.4 \\
\hline MV-2-27-1 & 41.3483 & 70.7063 & 9 & 2 & 140500 & 3600 & 33.4 & 3 \\
\hline$M V-2-27-2$ & 41.3633 & 70.7258 & 69 & 2.5 & 282500 & 7000 & 64.1 & 5.9 \\
\hline$M V-2-27-3$ & 41.3483 & 70.7482 & 30 & 2 & 106800 & 2800 & 24.8 & 2.3 \\
\hline MV-2-27-4 & 41.335 & 70.7977 & 33 & 2 & 75500 & 3200 & 17.5 & 1.7 \\
\hline MV-3-07-2 & 41.3758 & 70.732 & 54 & 2 & 246000 & 6100 & 56.3 & 5.2 \\
\hline MV-3-07-3 & 41.3417 & 70.8143 & 51 & 2.5 & 97100 & 3600 & 22.2 & 2.1 \\
\hline \multicolumn{9}{|l|}{ Buzzards Bay } \\
\hline BB-2-21-1 & 41.5500 & 70.6495 & 12 & 1.0 & 79800 & 3300 & 18.7 & 1.8 \\
\hline BB-2-24-1 & 41.5317 & 70.6588 & 24 & 2.0 & 88200 & 3100 & 20.6 & 1.9 \\
\hline BB-2-24-2 & 41.5317 & 70.6597 & 24 & 2.0 & 84500 & 3400 & 19.7 & 1.9 \\
\hline BB-2-29-1 & 41.5567 & 70.6458 & 24 & 2.0 & 92900 & 4100 & 21.7 & 2.1 \\
\hline BB-2-29-2 & 41.5567 & 70.6458 & 24 & 2.5 & 88300 & 6200 & 20.7 & 2.3 \\
\hline BB-3-06-1 & 41.5750 & 70.6178 & 24 & 2.5 & 89200 & 2900 & 20.9 & 1.9 \\
\hline BB-3-06-2 & 41.5783 & 70.6192 & 21 & 2.5 & 94600 & 3200 & 22.2 & 2.1 \\
\hline BB-3-06-3 & 41.5817 & 70.6217 & 21 & 2.5 & 92100 & 4000 & 21.6 & 2.1 \\
\hline BB-3-12-1 & 41.5250 & 70.6532 & 9 & 1.5 & 82500 & 4100 & 19.4 & 2 \\
\hline BB-3-12-2 & 41.5242 & 70.6528 & 18 & 2.0 & 93800 & 4600 & 22 & 2.2 \\
\hline
\end{tabular}

Table A1: Recalibrated ${ }^{10}$ Be ages from Balco et al. (2002)

a) Ages are calculated using the CRONUS-Earth calculator (Balco et al., 2008) and the regional productions rate of $3.93 \pm 0.19$ atoms $\mathrm{g}^{-1} \mathrm{a}^{-1}$ (Balco et al., 2009) .

b) Sample thickness corrections employ a measured rock density of $2.7 \mathrm{~g} \mathrm{~cm}^{-3}$

c) All ${ }^{10} \mathrm{Be}$ exposure ages are calculated with the time-invariant ' $\mathrm{St}$ ' scaling scheme of Stone (2000)

following Lal (1991). 


\begin{tabular}{|c|c|c|c|c|c|}
\hline Site & ${ }^{14}$ C Age (yr BP) & $\mathbf{\pm}(\mathbf{y r ~ B P )}$ & Cal ka & $\mathbf{\pm}$ Cal Ka & Probability Distribution \\
\hline Cushman Pond & 13150 & 50 & 15800 & 100 & 1.000 \\
\hline Deer Lake Bog & 13000 & 400 & 15490 & 650 & 1.000 \\
\hline Lost Pond & 12870 & 370 & 15290 & 630 & 1.000 \\
\hline Lake of the Clouds & 11530 & 420 & 13420 & 460 & 1.000 \\
\hline Pond of Safety & 12450 & 60 & 14590 & 220 & 1.000 \\
\hline Surplus Pond & 12250 & 55 & 14160 & 90 & 1.000 \\
\hline Spencer Pond & 11665 & 85 & 13500 & 80 & 1.000 \\
\hline Columbia Bridge & 11540 & 110 & 13370 & 100 & 1.000 \\
\hline Barnston Lake & 11020 & 330 & 12900 & 310 & 1.000 \\
\hline Lower Black Pond & 11500 & 50 & 13350 & 50 & 1.000 \\
\hline Chain of Ponds & 10860 & 160 & 12780 & 150 & 1.000 \\
\hline Lac aux Araignees & 10700 & 310 & 12520 & 400 & 1.000 \\
\hline Boundary Pond & 10200 & 200 & 11880 & 290 & 0.798 \\
\hline Lac a la Truite & 11000 & 240 & 12900 & 200 & 1.000 \\
\hline Lac Dufresne & 11200 & 160 & 13050 & 170 & 1.000 \\
\hline
\end{tabular}

Table A2: Recalibrated ${ }^{14} \mathrm{C}$ ages from Thompson et al. 1999 using CALIB 7.1 and IntCal 13. The probability distribution represents the likelihood of the representative age. 


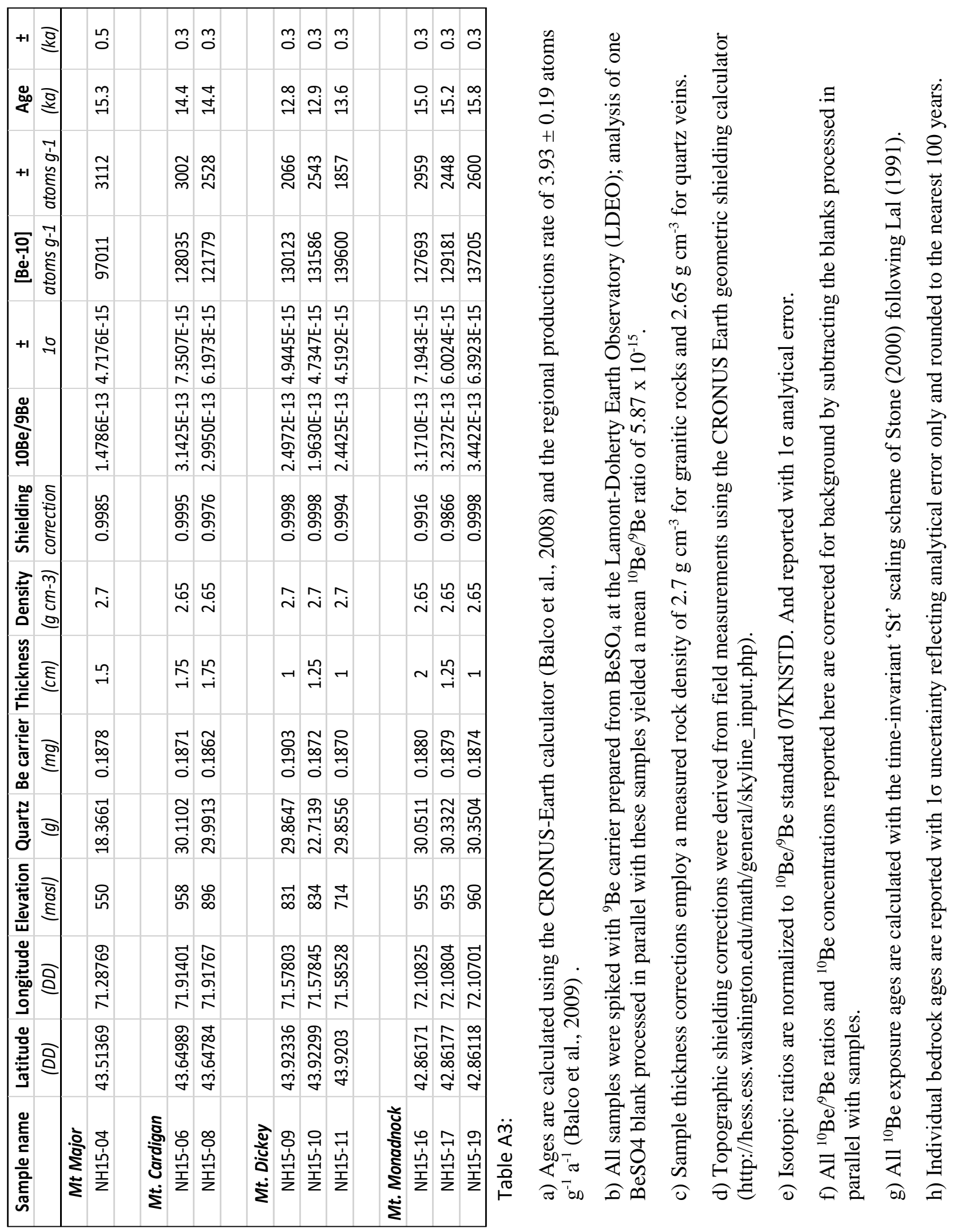

